Article

\title{
Effectiveness of Different Sample Treatments for the Elemental Characterization of Bees and Beehive Products
}

\author{
Maria Luisa Astolfi ${ }^{1, *}{ }^{(\mathbb{C}}$, Marcelo Enrique Conti ${ }^{2}$, Elisabetta Marconi $^{3}$, Lorenzo Massimi $^{1}{ }^{1}$ and \\ Silvia Canepari ${ }^{1}$ (D) \\ 1 Department of Chemistry, Sapienza University, Piazzale Aldo Moro 5, I-00185 Rome, Italy; \\ 1.massimi@uniroma1.it (L.M.); silvia.canepari@uniroma1.it (S.C.) \\ 2 Department of Management, Sapienza University, Via del Castro Laurenziano 9, I-00161 Rome, Italy; \\ marcelo.conti@uniroma1.it \\ 3 Department of Public Health and Infectious Diseases, Sapienza University, Piazzale Aldo Moro 5, \\ I-00185 Rome, Italy; elisabetta.marconi@uniroma1.it \\ * Correspondence: marialuisa.astolfi@uniroma1.it; Tel./Fax: +39-06-4991-3384
}

Academic Editors: Gavino Sanna, Yolanda Picò, Marco Ciulu, Carlo Tuberoso and Nadia Spano Received: 17 August 2020; Accepted: 15 September 2020; Published: 17 September 2020

\begin{abstract}
Bee health and beehive products' quality are compromised by complex interactions between multiple stressors, among which toxic elements play an important role. The aim of this study is to optimize and validate sensible and reliable analytical methods for biomonitoring studies and the quality control of beehive products. Four digestion procedures, including two systems (microwave oven and water bath) and different mixture reagents, were evaluated for the determination of the total content of 40 elements in bees and five beehive products (beeswax, honey, pollen, propolis and royal jelly) by using inductively coupled plasma mass and optical emission spectrometry. Method validation was performed by measuring a standard reference material and the recoveries for each selected matrix. The water bath-assisted digestion of bees and beehive products is proposed as a fast alternative to microwave-assisted digestion for all elements in biomonitoring studies. The present study highlights the possible drawbacks that may be encountered during the elemental analysis of these biological matrices and aims to be a valuable aid for the analytical chemist. Total elemental concentrations, determined in commercially available beehive products, are presented.
\end{abstract}

Keywords: sample preparation; trace element; toxic element; spectroanalytical technique; biomonitoring

\section{Introduction}

Various natural and anthropogenic emission sources of toxic elements may cause air pollution [1-6]. Among different air pollution monitoring techniques, biomonitoring has recently become one of the most widely used technique, due to its ease of operation, low cost, efficiency and specificity [7-10]. In fact, several living organisms, known as biomonitors, can accumulate toxic elements, allowing the monitoring of pollutants concentrations in the environment for integrated measurements over time [11-13]. The use of apis mellifera and beehive products for biomonitoring studies has been widely investigated [14-20] and reviewed [21-23]. Honeybees and the associated matrices are often considered as efficient sentinels for environmental biomonitoring [7,17]. Trace elements can be transferred to honeybees and beehive products from all the environmental compartments (soil, vegetation, air and water) in the areas covered by forager honeybees [24], within which honeybees and beehive products may supply integrated representative samples [25]. Measurements of element concentrations in honey samples are relevant for the healthiness assessment of the honey in terms of the presence of essential metals and for ensuring the human health safety by assessing the admissible levels of toxic elements [21]. Moreover, the assessment 
of element concentrations in honey is also useful for its classification based on its genuineness and its botanical and geographical origins [21].

Among the different instrumental methods used for the determination of elements in honeybee and beehive products, atomic and mass spectrometry are considered as the most sensitive, accurate, and robust techniques, thus being routinely and customarily applied [21,26,27]. Flame atomic absorption spectrometry (F-AAS) has been often employed for the low-cost and rapid determination of high concentrations of metals $[21,22,28]$. To control the quality of honey and other beehive products in terms of contamination by heavy metals, many sensitive techniques are required, including graphite furnace atomic absorption spectrophotometry (GF-AAS) [17,19], electrothermal atomic absorption spectrometry (ET-AAS) [29,30], microwave plasma technique atomic emission spectrometry (MP-AES) [31], inductively coupled plasma optical emission spectrometry (ICP-OES) [14,16,24,32-34], and inductively coupled plasma mass spectrometry (ICP-MS) [14,18,20,35-39]. In addition, other atomic techniques, such as atomic analyzer mercury (AMA), hydride generation-atomic absorption spectrometry (HG-AAS) and cold vapor atomic fluorescence spectrometry (CV-AFS), have been employed in environmental studies for the determination of $\mathrm{Hg}$, As and $\mathrm{Se}[40,41]$.

The analysis of biological samples by atomic and mass spectrometry techniques is a difficult and challenging task [21]. Honey and other beehive products are very complex organic matrices with problems related to the sample heterogeneity, selection of sample treatment, and decomposition as well chemical interferences during measurements $[21,22,38]$. Moreover, bees and beehive products are matrices with high $C$ contents [42-44] and their incomplete sample decomposition may cause a residual carbon content (RCC) in the final digests. During ICP analysis, the element signals with a similar ionization potential to that of $C$ is enhanced due to $C$ charge transfer reactions $[45,46]$. The residual acidity in the final digests is also important for the polyatomic interference (for ICP-MS), nebulization efficiency and for reducing the instrument interface damage [47-49]. Samples of honey and other beehive products are commonly decomposed using high temperature dry ashing $[17,50]$ or wet digestion procedures, in order to destroy the carbohydrate-rich sample matrix and minimize the matrix-based interferences [21,22]. To obtain an efficient honeybee and beehive products digestion, various reagents or mixtures are used, including concentrated $\mathrm{HNO}_{3}$ or other acids (such as $\mathrm{HCl}, \mathrm{HClO}_{4}$ and $\mathrm{H}_{2} \mathrm{SO}_{4}$ ), frequently mixed with $30 \% \mathrm{H}_{2} \mathrm{O}_{2}$, using open vessels or sealed quartz or polytetrafluoroethylene (PTFE) vessels in microwave-assisted systems [21,22,35,38,39]. Unfortunately, to date the validation of methods and procedures used for the analysis of bees and beehive products is difficult because no certified reference material (CRM) of these matrices is available. Instead, the trueness of the methods and procedures applied is commonly checked by the analysis of other CRMs containing high levels of carbohydrates, such as Antarctic krill (MURST-ISSA2), apple leaves (NIST 1515), brown bread (BCR 191), corn (NBS 8413), mixed Polish herbs (INCT-MPH-2), tea leaves (INCT-TL-1) and wheat (IPE 684) or whole meal flour (BCR 189) [21,22]. For the same purpose, the recovery tests are carried out on the chosen samples spiked with known amounts of selected elements [21,22,35].

Generally, among all beehive products, only honey [14,20,21,23,32,34,51-53] or honey and pollen $[17,24,35]$ are considered in the optimization approach for elemental determination with ICP techniques. To our knowledge, in the literature, few studies are focused on the elemental content of other beehive products such as propolis $[19,31,38]$ or royal jelly and beeswax [15].

Therefore, the aim of this study is to compare different methods of sample preparation, including two systems (microwave oven and water bath) and different mixture reagents, which will allow the assessment of the exposure of bees to different element concentrations and the quality control of beehive products in terms of contamination made by toxic elements in both routine and large-scale investigations. The optimized methods were employed to determine 40 elements ( $\mathrm{Al}, \mathrm{As}, \mathrm{B}, \mathrm{Ba}, \mathrm{Be}, \mathrm{Bi}$, $\mathrm{Ca}, \mathrm{Cd}, \mathrm{Co}, \mathrm{Cr}, \mathrm{Cs}, \mathrm{Cu}, \mathrm{Fe}, \mathrm{K}, \mathrm{Li}, \mathrm{Mg}, \mathrm{Mn}, \mathrm{Mo}, \mathrm{Na}, \mathrm{Ni}, \mathrm{P}, \mathrm{Pb}, \mathrm{Rb}, \mathrm{Sb}, \mathrm{Se}, \mathrm{Si}, \mathrm{Sn}, \mathrm{Sr}, \mathrm{Te}, \mathrm{Ti}, \mathrm{Tl}, \mathrm{U}, \mathrm{V}$, and Zn) with ICP techniques. The analytical performance and quality control of the optimized procedures were evaluated on CRMs and field samples of bees, beeswax, honey, honeydew, pollen, propolis and royal jelly. For this purpose, different commercially available beehive products were analyzed. 


\section{Results and Discussion}

\subsection{Preliminary Evaluation of Digestion Efficiency}

Preliminary tests were carried out in order to evaluate the effects of the reagent mixture, temperature and pressure on sample digestion, which was evaluated in digests by the RCC and residual acidity determination. $\mathrm{HNO}_{3}$ and $\mathrm{H}_{2} \mathrm{O}_{2}$ (methods $\mathrm{A}$ and $\mathrm{B}$ ) were preferred to other reagents $\left(\mathrm{HCl}, \mathrm{HClO}_{4}\right.$, or $\mathrm{H}_{2} \mathrm{SO}_{4}$ ) because they allow the oxidation of almost all organic compounds and cause minor spectral interferences or problems in ICP-MS [49]. The aqua regia digestion procedures (methods B1 and B2) were chosen for assessing the total recoverable elements in all samples [54-56]. The total elemental content is important information to evaluate and control the quality of honey and other beehive products in terms of contamination. A mixture of aqua regia has been widely used for the digestion of various solid wastes such as ashes, sludge, sediments and soils [54,56]. In addition, HF is effective in extracting silicate-bound elements [54,56]. To improve element recovery and to increase the reaction kinetics, oxidizing agents such as $\mathrm{H}_{2} \mathrm{O}_{2}$ were added in the digestion procedures [56,57]. The comparison of the results obtained by using the different sample digestion procedures (methods A, B, B1 and B2) allows for the evaluation of the elements that have not been completely recovered in the various considered matrices.

A selected tolerance level of the RCC in solution, lower than 200 or $2000 \mathrm{mg} \mathrm{L}^{-1}$, was considered appropriate for the subsequent analyses by ICP-MS or ICP-OES [58,59]. Preliminary experiments were performed using a fixed amount of $200 \mathrm{mg}$ of the sample to evaluate the minimum $\mathrm{HNO}_{3}$ amount that was sufficient to obtain suitable values of the RCC in the digests with methods A and B. In methods $\mathrm{A}$ and $\mathrm{B}, 67 \% \mathrm{HNO}_{3}$ was varied in order to achieve an efficient organic matter digestion, using an acid solution with a concentration as low as possible. Thus, digestion using two different $67 \% \mathrm{HNO}_{3}$ amounts ( 1 or $2 \mathrm{~mL}$ ) was tested. Using $1 \mathrm{~mL} \mathrm{HNO}_{3}$, final digests presented a yellow color with solid

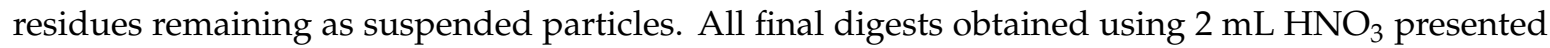
a colorless aspect, except for beeswax, which presented solid residues for both methods A and B. Thus, the RCC in digests (Figure 1) was lower than $231 \pm 2 \mathrm{mg} \mathrm{L}^{-1}$ in the pollen digests by method $\mathrm{A}$, and $155 \pm 12 \mathrm{mg} \mathrm{L}^{-1}$ in the propolis digests by method $\mathrm{B}$. The digestion efficiency was high when using both methods B1 and B2 with an RCC lower than $121 \pm 8$ and $99 \pm 21 \mathrm{mg} \mathrm{L}^{-1}$ (in the propolis digest), respectively.

The residual acidity was also determined in the final digests obtained from the digestion procedure performed with the $\mathrm{HNO}_{3} / \mathrm{H}_{2} \mathrm{O}_{2}$ mixture. The residual acidity was in the range $0.429 \pm 0.016-0.909$ $\pm 0.007 \mathrm{~mol} \mathrm{~L}^{-1}$ using microwave-assisted digestion, which showed a good digestion efficiency, while the activity was in the range $0.599 \pm 0.016-0.829 \pm 0.018 \mathrm{~mol} \mathrm{~L}^{-1}$ using water bath-assisted digestion. The results suggested that all the digests obtained using the four treatments were suitable for ICP-OES and ICP-MS analyses, except for pollen digests obtained by method A for ICP-MS analysis. Comparing the element concentrations in the digests obtained with all four digestion treatments, it is possible to verify if there is polyatomic ion interference due to the $C$ concentrations in the digested pollen by method A and analyzed with ICP-MS.

\subsection{Selection of ICP Instrument}

ICP-MS analysis is generally more susceptible to interferences than ICP-OES. Spectral interference in ICP-MS may be polyatomic and isobaric due to the presence of nonanalyte elements of a similar mass, such as species produced by plasma gas (Ar), atmosphere, nebulizer gas and matrix or combinations thereof $[58,60]$. Elemental analyses of biological matrices are commonly subjected to interferences caused by major constituents such as $\mathrm{C}, \mathrm{Ca}, \mathrm{Cl}, \mathrm{Mg}, \mathrm{N}, \mathrm{Na}$, and S [61,62]. The occurrence of spectral effects during the complex sample analysis seriously interferes with the determination of many isotopes, mainly up to $100 \mathrm{amu}$ [60-64]. Therefore, the collision-reaction interface (CRI) mode was used for the determination of $\mathrm{As}, \mathrm{Ca}, \mathrm{Co}, \mathrm{Cr}, \mathrm{Fe}, \mathrm{Mn}, \mathrm{Ni}, \mathrm{S}$, and $\mathrm{Se}$ in bees and beehive product samples, using $\mathrm{H}_{2}$ and $\mathrm{He}$ as cell gases. The first high ionization potential of $\mathrm{S}$ (10.357 eV) leads to a relatively low 
ionization efficiency in an Ar-based plasma [65]. The 34S isotope was selected for the determination of total S because of its lower spectral interferences [65]. The main drawback of the use of the CRI is the reduction in sensitivity when the collision or reaction gases are employed [65]. The best gas flow rates

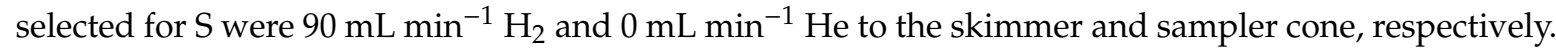
For this element, a comparison with ICP-OES was made. As shown in Figure S1, the correlation between the $S$ data obtained with ICP-MS and ICP-OES is not good. Hence, the ICP-OES determination of $S$ was preferable because it not affected by spectral interferences. The best compromise was obtained for As, Ca, Cr, Fe, Mn, and Se with a mixture of $30 \mathrm{~mL} \mathrm{~min}{ }^{-1} \mathrm{He}$ and $70 \mathrm{~mL} \mathrm{~min}^{-1} \mathrm{H}_{2}$ to the sampler and skimmer cones, respectively, in agreement with previously reported methods [60]. There were few differences between the standard and CRI mode measurements of 59Co and 60Ni; therefore, these elements were analyzed in the standard mode.
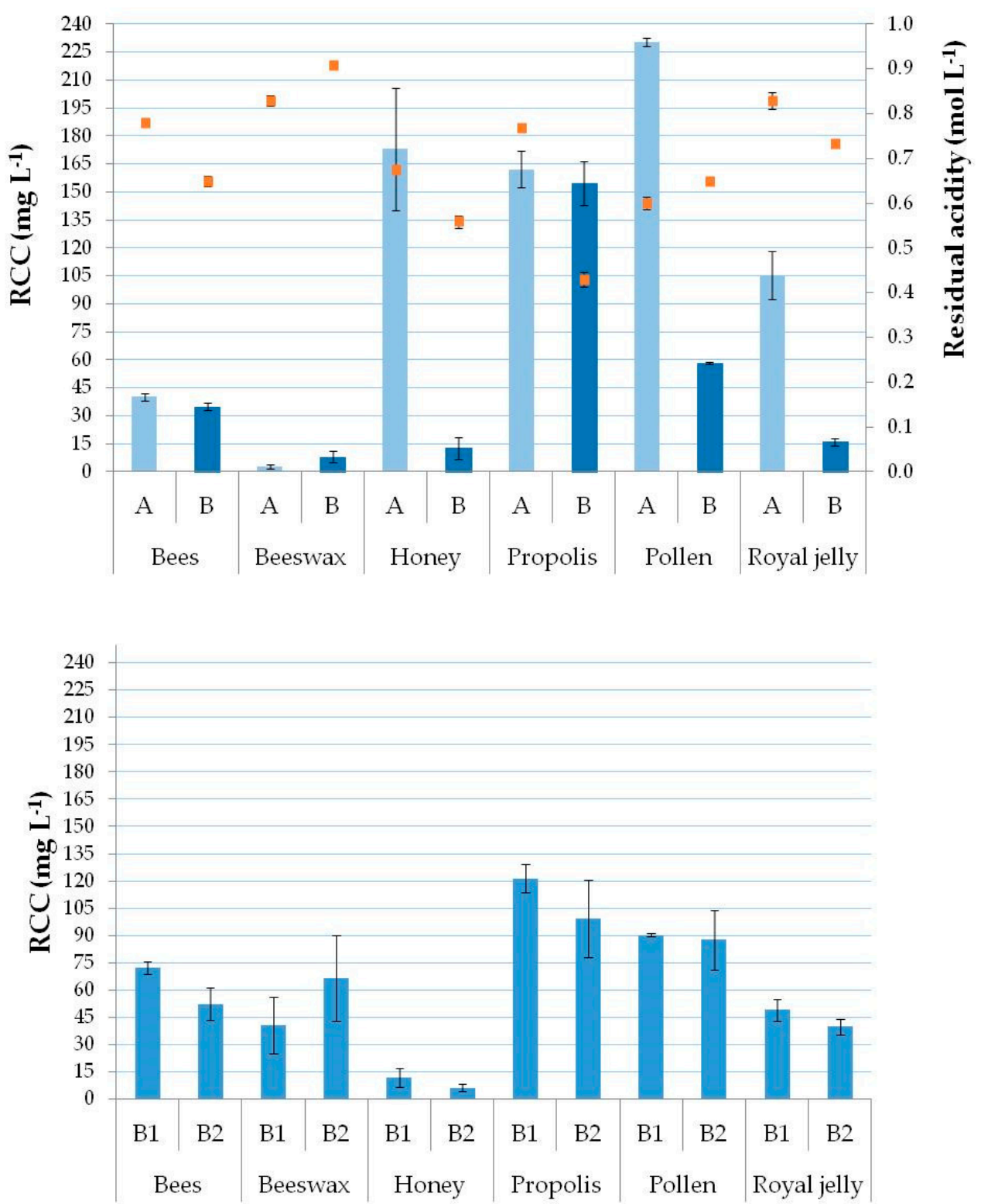

Figure 1. Sample treatment $(\mathrm{A}=$ open-vessel digestion heated with water bath, $\mathrm{B}=$ closed-vessel microwave-assisted digestion with $\mathrm{HNO}_{3} / \mathrm{H}_{2} \mathrm{O}_{2}$ mixture, $\mathrm{B} 1$ = closed-vessel microwave-assisted digestion with aqua regia/ $\mathrm{H}_{2} \mathrm{O}_{2}$ mixture, and $\mathrm{B} 2$ = closed-vessel microwave-assisted digestion with aqua regia/HF mixture) effect on bees and beehive products digestion efficiency. Bars represent residual carbon content (RCC; left $\mathrm{Y}$ axis; $n=3$ ) and line (-口-) represents residual acidity (right $\mathrm{Y}$ axis; $n=3$ ). 
The wide differences in the potential interferences and concentration ranges of the elements revealed that the use of both ICP techniques increases the accuracy for some elements. Specifically, the As, Be, Bi, Ce, Ga, Li, Nb, Pb, Sb, Se, Sn, Te, Tl, U, W, and Zr content of most samples were below the limit of detection (LOD) for the ICP-OES analysis (Tables S1-S6); whereas very high concentrations of some macroelements, especially $\mathrm{K}$, caused signal saturation in the ICP-MS analysis and required at least one additional dilution level for the analysis. Elements in the digests obtained by methods $\mathrm{A}$ and $\mathrm{B}$ were analyzed by both ICP-OES and ICP-MS instruments, while elements in the digests obtained by methods B1 and B2 were analyzed by ICP-OES only, to avoid the effect of interference in ICP-MS due to the presence of $\mathrm{HCl}$ or $\mathrm{HF}$.

\subsection{Analytical Performances}

\subsubsection{Linearity}

The linearity ranges for ICP-MS and ICP-OES analyses are shown in Table 1 and Table S7, respectively. The obtained correlation coefficients of all calibration curves were $>0.99$ and a good linearity was confirmed by a Mandel test [66].

\subsubsection{Limit of Detection and Quantification}

The LOD and limit of quantification (LOQ) for each element are shown in Table 1 and Table S7. LOD and LOQ values were of a similar magnitude to those previously reported $[67,68]$. With Regulation No. 2015/1005 [69], the European Union fixed a maximum level of $0.10 \mathrm{mg} \mathrm{kg}^{-1}$ for $\mathrm{Pb}$ in honey. No regulated standards are available to evaluate the other element levels in honey samples; therefore, Codex Alimentarius [70] stated that "honey shall be free from heavy metals in amounts which may represent a hazard to human health". Consequently, there is the need to determine very low concentrations of elements that may be present in honey in trace and ultratrace levels. The tested analytical methods using ICP-MS were sufficiently sensitive to quantify all the selected elements in bees and beehive products, including $\mathrm{Pb}$ that has an LOD value $\left(0.001 \mathrm{mg} \mathrm{kg}^{-1}\right) 100$ times lower than the maximum accepted level for honey [69].

\subsubsection{Precision, Trueness and Recovery Study}

An apple leaf CRM was used to evaluate the trueness and precision under the repeatability of the tested methods (Tables S8 and S9). This CRM was used because there are no suitable reference materials for bees and beehive products and because it is frequently used [21]. However, the matrix of the apple leaf CRM is a powder and has a chemical and elemental composition different from the bees and beehive products. According to Pohl et al. (2009) [21], the use of reference materials that contain large amounts of $C$ or carbohydrates can be very useful for the validation of the honey analysis method. Certified values of $\mathrm{As}, \mathrm{Be}, \mathrm{Bi}, \mathrm{Cs}, \mathrm{Ga}, \mathrm{Li}, \mathrm{Nb}, \mathrm{Se}, \mathrm{Si}, \mathrm{Sn}, \mathrm{Te}, \mathrm{Ti}, \mathrm{Tl}$, and $\mathrm{Zr}$ concentrations were not available for the CRM used so further testing is required for validation. As shown in Table S9, the trueness bias percentage and repeatability obtained by method B1 were estimated in the range from $-9.7(\mathrm{La})$ to $12.6 \%(\mathrm{Co})$ and from $2.6(\mathrm{~S})$ to $25 \%(\mathrm{Sb})$, respectively, and were improved from those obtained by the other tested methods (A, B and B2). The results of As, $\mathrm{Cr}$ and Se in the digests obtained by method B1 and analyzed by ICP-MS are higher because they are strongly affected by the interference due to $\mathrm{Cl}$. For this reason, we have chosen to report the data obtained with ICP-OES. To compare the observed results with the certified concentration of the CRM, the Z-scores were calculated [71]. Table S8 shows that the Z-scores of all elements excluding $\mathrm{Cd}, \mathrm{Rb}$ and $\mathrm{S}$ obtained by method $\mathrm{B} 1$ were smaller than 2, thus the results are considered acceptable. For $\mathrm{Cd}$ and $\mathrm{Rb}$, the results obtained by method B1 were underestimated compared to the certified values (Z-score $<-2)$, whereas they rather tend to be overestimated for $S$. 
Table 1. Limit of determination ${ }^{\mathrm{a}}\left(\mathrm{mg} \mathrm{kg}^{-1}\right)$ and linearity range for each element in bees and beehive products by inductively coupled plasma spectrometry.

\begin{tabular}{|c|c|c|c|c|c|c|c|c|}
\hline \multirow[b]{2}{*}{ Isotope/Element ${ }^{b}$} & \multirow[b]{2}{*}{$\begin{array}{c}\text { Internal } \\
\text { Standard }^{\mathrm{c}}\end{array}$} & \multicolumn{7}{|c|}{ LLOQ-ULOQ $^{\mathrm{d}} \mathrm{mg} \mathrm{kg}^{-1}$} \\
\hline & & $\mathrm{LOD}_{\mathrm{A}}$ & $\mathrm{LOD}_{\mathrm{B}}$ & LOD $_{\mathrm{B} 1}$ & $\mathbf{N}^{\mathrm{e}}$ & $\begin{array}{c}\text { Honey and } \\
\text { Beeswax }\end{array}$ & $\mathbf{N}^{\mathrm{e}}$ & $\begin{array}{c}\text { Bees, Pollen, } \\
\text { Propolis, and } \\
\text { Royal Jelly }\end{array}$ \\
\hline $27 \mathrm{Al}$ & $45 \mathrm{Sc}$ & 0.06 & 0.02 & 0.02 & 4 & $0.5-5$ & 5 & $1.05-21$ \\
\hline $75 \mathrm{As}^{\mathrm{f}}$ & $79 Y$ & 0.001 & 0.001 & - & 6 & $0.05-2$ & 6 & $0.05-2$ \\
\hline $11 \mathrm{~B}$ & $45 \mathrm{Sc}$ & 0.2 & 0.1 & 0.1 & 5 & $2.75-55$ & 5 & $2.75-55$ \\
\hline $137 \mathrm{Ba}$ & 115 In & 0.4 & 0.2 & 0.2 & 5 & $0.2-5$ & 4 & $7-100$ \\
\hline $9 \mathrm{Be}$ & $45 \mathrm{Sc}$ & 0.00002 & 0.00002 & 0.00002 & 7 & $0.05-5$ & 7 & $0.05-5$ \\
\hline 209Bi & $232 \mathrm{Th}$ & 0.00004 & 0.00006 & 0.00005 & 6 & $0.05-2$ & 6 & $0.05-2$ \\
\hline $44 \mathrm{Ca}$ & $79 Y$ & 11 & 5 & 14 & 4 & $100-1000$ & 4 & $1000-10000$ \\
\hline $112 \mathrm{Cd}$ & $115 \mathrm{In}$ & 0.00004 & 0.00001 & 0.00001 & 7 & $0.05-110$ & 7 & $0.05-110$ \\
\hline $140 \mathrm{Ce}$ & $115 \operatorname{In}$ & 0.00006 & 0.00004 & 0.0001 & 5 & $0.25-5$ & 5 & $0.25-5$ \\
\hline 59Co & $45 \mathrm{Sc}$ & 0.0005 & 0.0004 & 0.0008 & 6 & $0.25-10$ & 6 & $0.25-10$ \\
\hline $52 \mathrm{Crf}$ & $79 Y$ & 0.001 & 0.0008 & - & 7 & $0.05-5$ & 4 & 1-10 \\
\hline $133 \mathrm{Cs}$ & 115 In & 0.00004 & 0.00002 & 0.00001 & 7 & $0.05-5$ & 7 & $0.05-5$ \\
\hline $65 \mathrm{Cu}$ & $79 Y$ & 0.003 & 0.002 & 0.002 & 6 & $0.05-2$ & 9 & $0.1-100$ \\
\hline $56 \mathrm{Fe}$ & $79 Y$ & 0.02 & 0.01 & 0.01 & 4 & $1-10$ & 9 & $2.5-5000$ \\
\hline $71 \mathrm{Ga}$ & $79 Y$ & 0.00005 & 0.00001 & 0.00001 & 4 & $0.1-1$ & 4 & $0.1-1$ \\
\hline $39 K$ & $45 \mathrm{Sc}$ & 5 & 3 & 0.7 & 6 & $50-2500$ & 6 & $50-2500$ \\
\hline $139 \mathrm{La}$ & 115In & 0.00004 & 0.00006 & 0.00005 & 7 & $0.05-5$ & 7 & $0.05-5$ \\
\hline $7 \mathrm{Li}$ & $45 \mathrm{Sc}$ & 0.0008 & 0.0008 & 0.0005 & 7 & $0.05-5$ & 7 & $0.05-5$ \\
\hline $24 \mathrm{Mg}$ & $45 \mathrm{Sc}$ & 0.9 & 0.3 & 1.0 & 5 & $100-2500$ & 5 & $50-1000$ \\
\hline $55 \mathrm{Mn}$ & $79 Y$ & 0.002 & 0.002 & 0.003 & 4 & $0.2-2$ & 6 & $5.2-200$ \\
\hline $98 \mathrm{Mo}$ & 103Rh & 0.0003 & 0.0001 & 0.0001 & 7 & $0.05-110$ & 7 & $0.05-110$ \\
\hline $23 \mathrm{Na}$ & $45 \mathrm{Sc}$ & 0.6 & 0.4 & 0.3 & 5 & $100-2500$ & 7 & $25-2000$ \\
\hline $93 \mathrm{Nb}$ & $103 R h$ & 0.00001 & 0.000007 & 0.00002 & 5 & $0.05-1$ & 5 & $0.05-1$ \\
\hline $60 \mathrm{Ni}$ & $45 \mathrm{Sc}$ & 0.002 & 0.003 & 0.003 & 6 & $0.05-2$ & 7 & $0.2-20$ \\
\hline $31 \mathrm{P}$ & $45 \mathrm{Sc}$ & 0.7 & 1 & 0.7 & 5 & 5-100 & 4 & $1100-5000$ \\
\hline $208 \mathrm{~Pb}$ & $232 \mathrm{Th}$ & 0.001 & 0.001 & 0.001 & 7 & $0.05-5$ & 4 & 7-100 \\
\hline $85 \mathrm{Rb}$ & $79 Y$ & 0.0003 & 0.0003 & 0.00007 & 5 & $0.05-1$ & 4 & 20-200 \\
\hline $121 \mathrm{Sb}$ & 115In & 0.0004 & 0.0002 & 0.0001 & 7 & $0.05-5$ & 7 & $0.05-5$ \\
\hline $76 \mathrm{Se}$ & $79 Y$ & 0.02 & 0.007 & 0.01 & 4 & $0.2-2$ & 4 & $0.2-2$ \\
\hline $28 \mathrm{Si}$ & $45 \mathrm{Sc}$ & 9 & 8 & 10 & 4 & $10-100$ & 4 & $50-500$ \\
\hline $118 \mathrm{Sn}$ & 115In & 0.0002 & 0.0001 & 0.0001 & 7 & $0.05-5$ & 7 & $0.05-5$ \\
\hline $88 \mathrm{Sr}$ & $79 Y$ & 0.008 & 0.02 & 0.02 & 5 & $5.5-110$ & 5 & $5.5-110$ \\
\hline $125 \mathrm{Te}$ & 115In & 0.0003 & 0.0003 & 0.0002 & 5 & $0.05-1$ & 5 & $0.05-1$ \\
\hline $49 \mathrm{Ti}$ & $45 \mathrm{Sc}$ & 0.002 & 0.003 & 0.0007 & 9 & $0.05-50$ & 9 & $0.05-50$ \\
\hline $205 \mathrm{Tl}$ & $232 \mathrm{Th}$ & 0.00006 & 0.00003 & 0.00001 & 5 & $0.05-1$ & 5 & $0.05-1$ \\
\hline $238 \mathrm{U}$ & $232 \mathrm{Th}$ & 0.00001 & 0.00001 & 0.00001 & 7 & $0.05-5$ & 7 & $0.05-5$ \\
\hline $51 \mathrm{~V}$ & $79 Y$ & 0.0003 & 0.0006 & 0.00003 & 6 & $0.1-5$ & 4 & $1-10$ \\
\hline $182 \mathrm{~W}$ & $232 \mathrm{Th}$ & 0.0003 & 0.0002 & 0.00006 & 7 & $0.05-5$ & 7 & $0.05-5$ \\
\hline $66 \mathrm{Zn}$ & $79 Y$ & 0.09 & 0.04 & 0.09 & 5 & $2-50$ & 4 & $70-1000$ \\
\hline $90 \mathrm{Zr}$ & $79 Y$ & 0.0001 & 0.00009 & 0.0001 & 6 & $0.05-2$ & 6 & $0.05-2$ \\
\hline
\end{tabular}

${ }^{a} \mathrm{LOD}_{\mathrm{A}}, \mathrm{LOD}_{\mathrm{B}}$, and $\mathrm{LOD}_{\mathrm{B} 1}$ are the limits of determination for methods $\mathrm{A}, \mathrm{B}$, and $\mathrm{B} 1$, respectively. ${ }^{\mathrm{b}}$ Isotopes are reported for all the analyzed elements by inductively coupled plasma mass spectrometry (ICP-MS). ${ }^{c} \mathrm{Rh}$ replaces $\mathrm{Y}$ for propolis samples. ${ }^{d}$ LLOQ, lower limit of quantification; ULOQ upper limit of quantification. ${ }^{e} \mathrm{~N}$, number of calibration points for honey and beeswax or bees, pollen, propolis and royal jelly. ${ }^{\mathrm{f}} \mathrm{As}$ and $\mathrm{Cr}$ in digests obtained by method B1 are determined with inductively coupled plasma optical emission spectrometry (ICP-OES).

With the lack of a suitable CRM, spiked samples were also used to determine the elemental recoveries by methods $\mathrm{A}$ and $\mathrm{B}$, in accordance with previous studies [35]. It is worth mentioning that the study of recoveries does not allow for the assessment of the efficiency of the digestion procedure in decomposing the sample matrix but only enables the evaluation of matrix effects and losses or increases in a concentration of elements compared to the added amounts. All six sample matrices were spiked with two concentrations (the third and fifth instrumental calibration standards) before sample digestion. Recoveries for all elements fell within $20 \%$ of the expected value, with many of the elements recovering within $10 \%$, excluding $\mathrm{Al}, \mathrm{Ca}, \mathrm{Ce}$ and $\mathrm{Zn}$ in beeswax, Ce in royal jelly, Ba, $\mathrm{Cs}, \mathrm{Ga}, \mathrm{K}, \mathrm{Mn}$, $\mathrm{Na}, \mathrm{Nb}, \mathrm{P}, \mathrm{Ti}$ and $\mathrm{Zn}$ in bees, and $\mathrm{Al}, \mathrm{As}, \mathrm{Si}$, Ti and $\mathrm{Tl}$ in propolis by both methods $\mathrm{A}$ and $\mathrm{B}$, which fell within $30 \%$ (Table 2). The within-run precision for all the elements in honey and royal jelly and for most of the elements in other matrices was less than $10 \%$. The intermediate precision was less than $15 \%$ for most of the elements in all matrices excluding As and Se in the digests by method A, and As, $\mathrm{Ba}, \mathrm{Be}, \mathrm{Bi}, \mathrm{Cd}, \mathrm{Cr}, \mathrm{Pb}$ and Te in the digests by method $\mathrm{B}$ (Table 2). 
Table 2. Summary of precision (repeatability as percent coefficient of variation intrarun $(\% \mathrm{CVr})$ and reproducibility as \%CVR inter-run), and percent recovery (\%R) ranges for each element in working bee and beehive products applying two different digestion methods prior to analysis by ICP-MS and ICP-OES (for S).

\begin{tabular}{|c|c|c|c|c|c|c|}
\hline \multirow{2}{*}{ Isotope/Element ${ }^{\text {a }}$} & \multicolumn{3}{|c|}{ Method A } & \multicolumn{3}{|c|}{ Method B } \\
\hline & $\begin{array}{c}\% \text { CVr Intraday } \\
(n=3)\end{array}$ & $\begin{array}{c}\text { \%CVR Interday } \\
(n=9)\end{array}$ & $\% \mathbf{R}(n=3)$ & $\begin{array}{c}\% \text { CVr Intraday } \\
(n=3)\end{array}$ & $\begin{array}{c}\% \text { CVR Interday } \\
(n=9)\end{array}$ & $\% \mathrm{R}(n=3)$ \\
\hline${ }^{27} \mathrm{Al}$ & $1.8-24$ & $1.5-25$ & $96-126$ & $5.4-27$ & $15-25$ & $97-124$ \\
\hline${ }^{75}$ As & $1.8-21$ & $17-27$ & $88-124$ & $5.0-29$ & $17-30$ & 90-119 \\
\hline${ }^{11} \mathrm{~B}$ & $0.2-24$ & $6.5-19$ & $84-102$ & $2.2-32$ & $7.6-25$ & $86-100$ \\
\hline${ }^{137} \mathrm{Ba}$ & $0.6-23$ & $11-25$ & $103-122$ & $1.2-21$ & $17-30$ & $101-112$ \\
\hline${ }^{9} \mathrm{Be}$ & $0.9-13$ & $8.2-24$ & 86-97 & $14-22$ & $21-30$ & 90-101 \\
\hline${ }^{209} \mathrm{Bi}$ & $1.8-17$ & $11-21$ & 85-107 & $3.1-25$ & $19-31$ & $86-110$ \\
\hline${ }^{44} \mathrm{Ca}$ & $1.4-12$ & $7.2-25$ & 79-127 & $5.7-26$ & $14-26$ & $82-127$ \\
\hline${ }^{112} \mathrm{Cd}$ & $0.7-19$ & $9.1-25$ & $83-100$ & $1.5-22$ & $19-30$ & 83-104 \\
\hline${ }^{140} \mathrm{Ce}$ & $1.1-19$ & $8.7-26$ & $96-123$ & $1.0-25$ & $10-30$ & 98-119 \\
\hline${ }^{59} \mathrm{Co}$ & $0.8-13$ & $1.1-25$ & 81-105 & $0.4-27$ & $9.2-27$ & 84-102 \\
\hline${ }^{52} \mathrm{Cr}$ & $0.7-19$ & $2.0-22$ & 91-101 & $8.9-26$ & $20-31$ & 94-107 \\
\hline${ }^{133} \mathrm{Cs}$ & $0.7-6.4$ & $9.1-25$ & 99-123 & 3.3-14 & $3.3-30$ & 99-119 \\
\hline${ }^{65} \mathrm{Cu}$ & $1.3-23$ & $4.6-23$ & $82-121$ & $1.1-18$ & $5.4-28$ & $87-111$ \\
\hline${ }^{56} \mathrm{Fe}$ & $0.5-7.7$ & $3.6-13$ & $88-120$ & $0.9-25$ & $5.9-25$ & $92-116$ \\
\hline${ }^{71} \mathrm{Ga}$ & $1.2-23$ & $13-24$ & $83-130$ & $1.1-25$ & 7.4-31 & $86-130$ \\
\hline${ }^{39} \mathrm{~K}$ & $0.9-22$ & $1.3-21$ & $87-124$ & $0.8-10$ & $6.7-13$ & $87-121$ \\
\hline${ }^{139} \mathrm{La}$ & $1.2-10$ & $5.0-24$ & 90-114 & $0.5-24$ & $8.1-29$ & $92-114$ \\
\hline${ }^{7} \mathrm{Li}$ & $0.2-11$ & $3.8-24$ & 90-118 & $1.5-23$ & $14-21$ & $90-120$ \\
\hline${ }^{24} \mathrm{Mg}$ & $0.01-9.0$ & $5.2-25$ & $82-108$ & $0.5-19$ & $7.0-23$ & $82-110$ \\
\hline${ }^{55} \mathrm{Mn}$ & $0.4-17$ & $12-25$ & $84-125$ & $0.7-24$ & $3.7-24$ & 86-115 \\
\hline${ }^{98} \mathrm{Mo}$ & $0.3-6$ & $10-25$ & 95-117 & $1.9-25$ & $1.9-25$ & 94-114 \\
\hline${ }^{23} \mathrm{Na}$ & $0.6-6.7$ & $4.9-21$ & $80-125$ & $2.2-17$ & $6.5-26$ & $84-122$ \\
\hline${ }^{93} \mathrm{Nb}$ & $1.5-20$ & $8.0-24$ & $85-122$ & $3.6-22$ & $11-27$ & $86-116$ \\
\hline${ }^{60} \mathrm{Ni}$ & $0.9-17$ & $13-22$ & $83-97$ & $0.4-23$ & $8.6-29$ & $82-99$ \\
\hline${ }^{31} \mathrm{P}$ & $0.5-11$ & $4.2-20$ & $80-122$ & $0.5-23$ & $5.7-25$ & $81-123$ \\
\hline${ }^{208} \mathrm{~Pb}$ & $1.6-23$ & $12-24$ & $80-121$ & $2.7-24$ & $16-27$ & $86-116$ \\
\hline${ }^{85} \mathrm{Rb}$ & $3.6-11$ & $4.5-25$ & $96-120$ & $0.8-23$ & $7.3-30$ & $92-117$ \\
\hline $\mathrm{S}$ & $7.5-9.1$ & $6.8-11$ & $96-110$ & $1.7-10$ & $4.1-11$ & $97-111$ \\
\hline${ }^{121} \mathrm{Sb}$ & $0.2-17$ & $11-26$ & $81-100$ & $13-23$ & $15-27$ & $84-98$ \\
\hline${ }^{76} \mathrm{Se}$ & $0.4-18$ & $16-26$ & 83-108 & $3.4-24$ & $13-30$ & $82-102$ \\
\hline${ }^{28} \mathrm{Si}$ & $1.4-15$ & $4.2-26$ & $101-126$ & $1.8-21$ & $4.1-28$ & $98-122$ \\
\hline${ }^{118} \mathrm{Sn}$ & $2.0-14$ & $5.7-26$ & 81-101 & $2.7-23$ & $15-31$ & 86-101 \\
\hline${ }^{88} \mathrm{Sr}$ & $1.3-15$ & $0.6-25$ & 89-121 & $0.5-24$ & $15-34$ & 84-119 \\
\hline${ }^{125} \mathrm{Te}$ & $0.7-15$ & $7.0-26$ & $81-89$ & $3.0-17$ & $27-30$ & $81-90$ \\
\hline${ }^{49} \mathrm{Ti}$ & $1.2-22$ & $6.8-18$ & $95-128$ & $0.2-19$ & $3.5-30$ & $96-118$ \\
\hline${ }^{205} \mathrm{Tl}$ & $1.6-19$ & $13-20$ & $94-124$ & $1.0-19$ & $11-24$ & $96-120$ \\
\hline${ }^{238} \mathrm{U}$ & $1.7-21$ & $9.8-29$ & $87-110$ & $1.9-21$ & $15-26$ & $87-110$ \\
\hline${ }^{51} \mathrm{~V}$ & $0.3-19$ & $9.4-25$ & $83-111$ & $1.2-22$ & $10-30$ & $86-106$ \\
\hline${ }^{182} \mathrm{~W}$ & $1.8-7$ & $19-26$ & $84-113$ & $0.6-15$ & $11-30$ & $84-116$ \\
\hline${ }^{66} \mathrm{Zn}$ & $0.3-24$ & $5.2-25$ & $88-126$ & $1.3-21$ & $10-29$ & $86-124$ \\
\hline${ }^{90} \mathrm{Zr}$ & $1.2-21$ & $11-25$ & 90-112 & $2.3-17$ & $13-31$ & $92-114$ \\
\hline
\end{tabular}

${ }^{\mathrm{a}}$ Isotopes were reported for all the analyzed elements by ICP-MS. Sulfur was determined by ICP-OES.

\subsubsection{Mixture Reagent Digestion}

The method's accuracy is very important for biomonitoring studies to control the quality of beehive products and to compare the results obtained from different samples. The variation of the elemental concentrations for each matrix must depend only on the variations of the environmental contamination and not on the selected method. The accuracy of the results allows for the assessment of the contamination in each matrix. For this purpose, a single homogeneous sample for each considered matrix was analyzed with the different digestion methods in order to estimate recovery and precision. Comparing the native data in the matrices (Figures 2-4) normalized with respect to method $\mathrm{B}$, the greatest differences observed between the results of $\mathrm{Al}, \mathrm{B}, \mathrm{Ba}, \mathrm{K}, \mathrm{Mn}, \mathrm{P}, \mathrm{S}, \mathrm{Ti}, \mathrm{V}$, and $\mathrm{Zn}$ in bees; $\mathrm{Al}, \mathrm{Cr}, \mathrm{Fe}, \mathrm{Mg}$, and $\mathrm{Ti}$ in beeswax, $\mathrm{Al}, \mathrm{B}, \mathrm{Ba}, \mathrm{K}$, and $\mathrm{Mg}$ in honey, $\mathrm{Al}, \mathrm{B}, \mathrm{Ba}, \mathrm{Cr}, \mathrm{Na}, \mathrm{P}, \mathrm{Si}$, Ti, and $\mathrm{Zn}$ in pollen, $\mathrm{Al}, \mathrm{B}, \mathrm{Ba}, \mathrm{Be}, \mathrm{Ca}, \mathrm{Cd}, \mathrm{Ce}, \mathrm{Co}, \mathrm{Cr}, \mathrm{Cu}, \mathrm{Li}, \mathrm{Mn}, \mathrm{P}, \mathrm{Pb}, \mathrm{S}, \mathrm{Si}, \mathrm{Ti}, \mathrm{V}, \mathrm{Zn}$, and $\mathrm{Zr}$ in propolis, and $\mathrm{Al}, \mathrm{Na}$, and $\mathrm{S}$ in royal jelly were due to the use of different digestion mixtures and not to the use of 
different digestion systems. Se, and Te in bees, B, Ba, Bi, Ga, Nb, Ni, Se, Si, Te, V, and $\mathrm{W}$ in beeswax, $\mathrm{Be}, \mathrm{Bi}, \mathrm{Cd}, \mathrm{Nb}, \mathrm{Ni}, \mathrm{Pb}$, Se, Te, V, and $\mathrm{W}$ in honey, Bi, Se, Te, and $\mathrm{W}$ in pollen, $\mathrm{As}, \mathrm{Ba}, \mathrm{Bi}, \mathrm{Cd}, \mathrm{Ga}, \mathrm{Nb}$, $\mathrm{Ni}, \mathrm{Pb}, \mathrm{Te}, \mathrm{V}$, and $\mathrm{W}$ in royal jelly were not considered since they were always $<\mathrm{LOD}$. Considering all the methods with the use of microwave oven, the reagent mixtures used in methods B1 and B2 allow a greater extraction of the elements in the different matrices compared to the method B. The extraction capacity of the digestion reagent mixtures depends on the chemical compounds present in the various analyzed matrices. The higher temperatures and pressure that occur with the use of the microwave oven compared to the water bath affected the content of $\mathrm{Ba}, \mathrm{Be}, \mathrm{Bi}, \mathrm{Ga}, \mathrm{Mn}, \mathrm{Nb}, \mathrm{P}, \mathrm{Pb}$, $\mathrm{S}, \mathrm{Sn}$, and $\mathrm{Sr}$ in bees, $\mathrm{Al}, \mathrm{Be}, \mathrm{Cd}, \mathrm{Co}, \mathrm{Cr}, \mathrm{Cu}, \mathrm{Fe}, \mathrm{Li}, \mathrm{Rb}, \mathrm{Sb}, \mathrm{Ti}, \mathrm{Tl}$, and $\mathrm{Zr}$ in beeswax, As, Ba, Cr, Li, $\mathrm{Mo}$, and $\mathrm{Zr}$ in honey, $\mathrm{Al}, \mathrm{As}, \mathrm{Be}, \mathrm{Ce}, \mathrm{Cr}, \mathrm{La}, \mathrm{Li}, \mathrm{Rb}, \mathrm{Ti}, \mathrm{U}, \mathrm{V}$, and $\mathrm{Zn}$ in pollen, Al, Ba, Ga, Li, Se, Si, $\mathrm{Sn}, \mathrm{Ti}, \mathrm{V}, \mathrm{W}$, and $\mathrm{Zr}$ in propolis, and $\mathrm{Al}, \mathrm{Cr}, \mathrm{Cs}, \mathrm{Sb}, \mathrm{Si}$, and $\mathrm{U}$ in royal jelly. Tables S1-S6 show that methods $\mathrm{A}$ and $\mathrm{B}$ gave similar results for all the elements excluding $\mathrm{Ga}$ in bees, $\mathrm{La}, \mathrm{Mo}$, and $\mathrm{Ti}$ in honey, Be, Ce, La, Li, U, and V in pollen, Se in propolis, and $\mathrm{Cr}$ and $\mathrm{Si}$ in royal jelly. The total content of the following elements in the selected matrices can only be obtained by using aqua regia mixtures: $\mathrm{Al}$, $\mathrm{B}, \mathrm{Ba}, \mathrm{Cr}, \mathrm{P}$, and $\mathrm{S}$ in bees; $\mathrm{Ba}, \mathrm{P}$, and Ti in beeswax; $\mathrm{Al}$, and $\mathrm{Ba}$ in honey; $\mathrm{Al}, \mathrm{B}, \mathrm{Ba}, \mathrm{Cr}, \mathrm{Cu}, \mathrm{Fe}, \mathrm{Na}, \mathrm{S}, \mathrm{Si}$, and $\mathrm{Ti}$ in pollen; $\mathrm{Al}, \mathrm{B}, \mathrm{Ba}, \mathrm{Be}, \mathrm{Ca}, \mathrm{Cd}, \mathrm{Co}, \mathrm{Cr}, \mathrm{Li}, \mathrm{Mg}, \mathrm{Si}, \mathrm{Sn}, \mathrm{Ti}, \mathrm{V}, \mathrm{Zn}$, and $\mathrm{Zr}$ in propolis; $\mathrm{Na}$, and $\mathrm{P}$ in royal jelly. The improvements and optimal recoveries of $\mathrm{Al}, \mathrm{Ba}, \mathrm{Fe}$, and $\mathrm{Sb}$ from a variety of matrices upon the addition of $\mathrm{HCl}$ have been demonstrated [56,72]. However, treatment with $\mathrm{HNO}_{3}$ favors $\mathrm{Cl}$ elimination as nitrosyl chloride and minimizes the isobaric interferences in the case of some elements (As, Cr, Fe, Mn, Ni, Se and V) analyzed by ICP-MS [60,73].

In agreement with other studies [35], the procedure $\mathrm{A}$ is a good alternative to the procedure $\mathrm{B}$ because it limits sample manipulation, does not require the cleaning of sample vessels between analyses and allows 120 samples to be processed in $30 \mathrm{~min}$. However, the content of some elements in specific matrices can be underestimated using the reactive digestion mixture $\mathrm{HNO}_{3} / \mathrm{H}_{2} \mathrm{O}_{2}$. The data reported in the present study aim to be a valuable help for choosing the most appropriated methods and analytical techniques for the determination of each element in bees and beehive products.

\subsection{Analysis of Commercial Beehive Products}

Commercial beehive samples were analyzed in order to demonstrate the applicability of the optimized methods. Concentrations were above the LODs for most of the elements, including $\mathrm{Pb}$, showing that both methods A (Table 3) and B (Tables S10 and S11) can be used to determine the elemental composition of beehive products. Both methods $\mathrm{A}$ and $\mathrm{B}$ provided similar concentration data for the elements above the LODs. However, the average levels of some elements (La, Mo, and Ti in honey; Be, Ce, La, Li, U, and V in pollen; Se in propolis; $\mathrm{Cr}$ and $\mathrm{Si}$ in royal jelly) obtained with method B were higher. Methods A and B allow the elemental characterization of bees and beehive products, except for some elements that were underestimated with respect to the data acquired with methods B1 and B2, as reported in Section 2.3.4. 

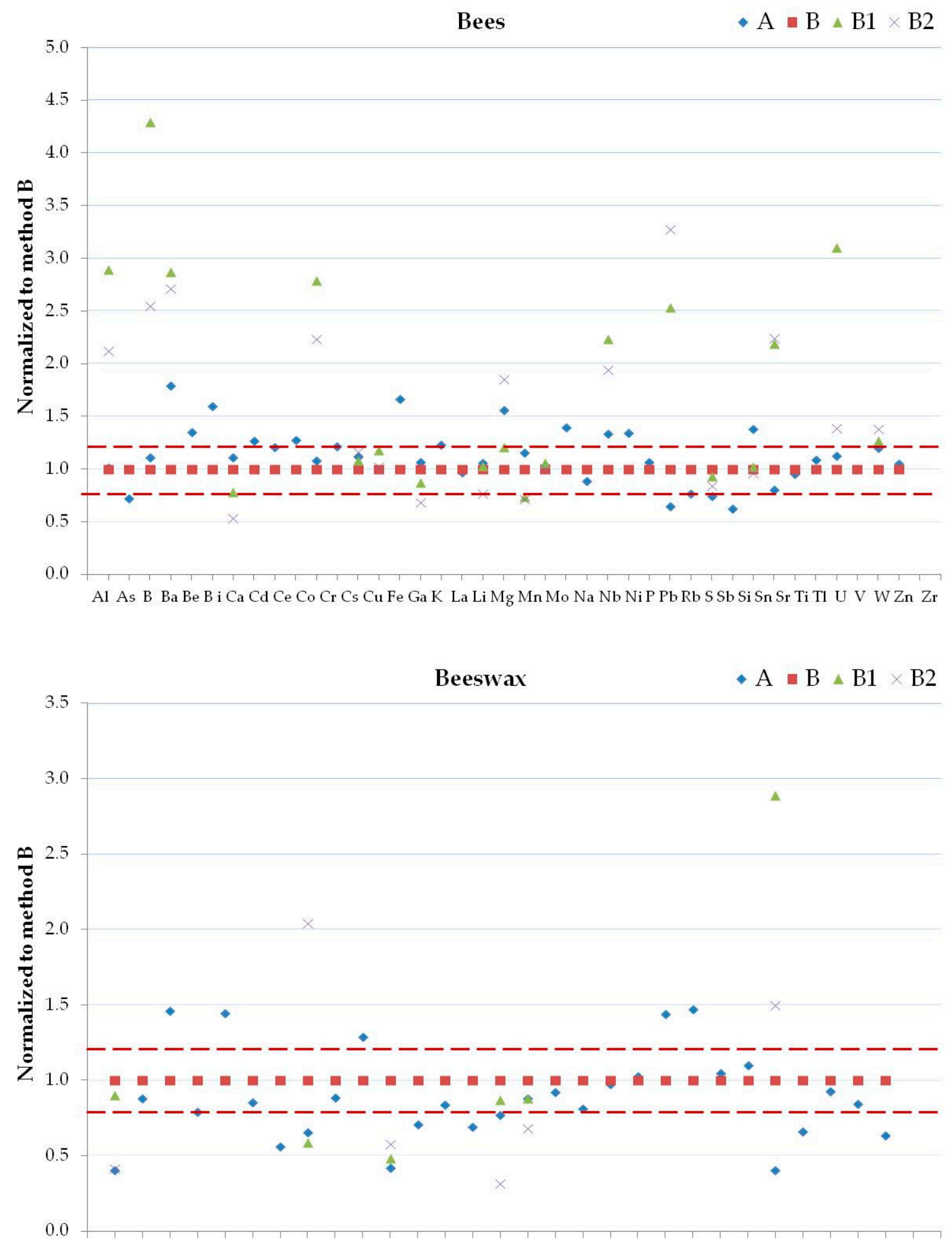

Al As Be Ca Cd Ce Co Cr Cs Cu Fe K La Li Mg Mn Mo Na P Pb Rb Sb Sn Sr Ti Tl U Zn Zr

Figure 2. Normalized concentrations to results obtained by method B1 of detected elements in bees (top panel) and beeswax (bottom panel) samples by methods A, B, B1 and B2. Dashed lines are $\pm 20 \%$. 

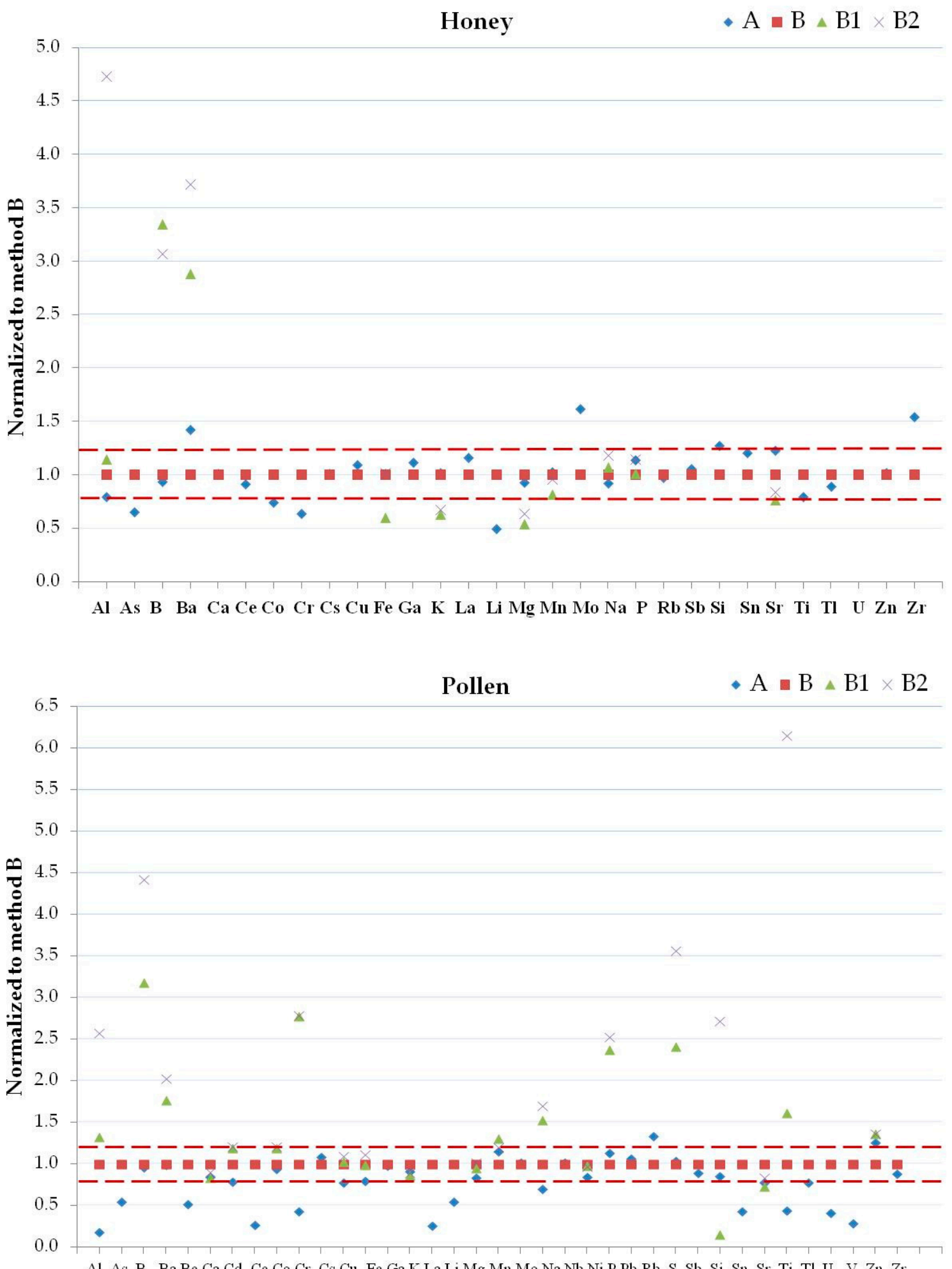

Al As B BaBe CaCd Ce Co Cr Cs Cu Fe GaKLa Li Mg Mn Mo Na Nb Ni P Pb Rb s sb Si Sn sr Ti Tl U V Zn Zr

Figure 3. Normalized concentrations to results obtained by method B1 of detected elements in honey (top panel) and pollen (bottom panel) samples by methods A, B, B1 and B2. Dashed lines are $\pm 20 \%$. 

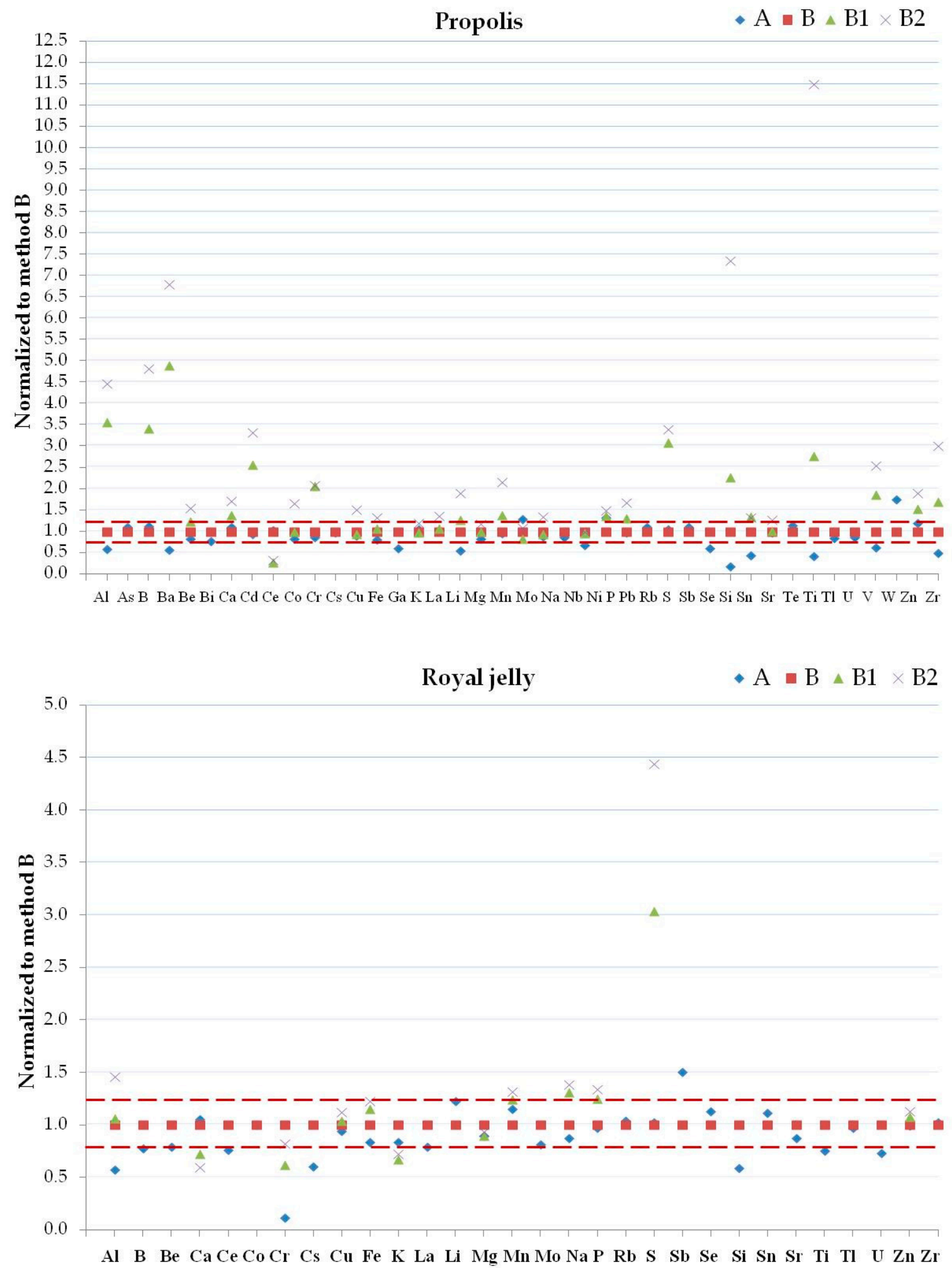

Figure 4. Normalized concentrations to results obtained by method B1 of detected elements in propolis (top panel) and royal jelly (bottom panel) samples by methods A, B, B1 and B2. Dashed lines are $\pm 20 \%$. 
Table 3. Concentrations $\left(\mathrm{mg} \mathrm{Kg}^{-1}\right)$ of each element in some commercial apiary products obtained by method A.

\begin{tabular}{|c|c|c|c|c|c|c|c|c|c|c|c|c|c|c|c|c|c|c|c|c|}
\hline \multirow{2}{*}{ Element } & \multicolumn{2}{|c|}{ Honey 1} & \multicolumn{2}{|c|}{ Honey 2} & \multicolumn{2}{|c|}{ Honey 3} & \multicolumn{2}{|c|}{ Honey 4} & \multicolumn{2}{|c|}{ Honey 5} & \multicolumn{2}{|c|}{ Honeydew 1} & \multicolumn{2}{|c|}{ Honeydew 2} & \multicolumn{2}{|c|}{ Beeswax } & \multicolumn{2}{|c|}{ Pollen } & \multicolumn{2}{|c|}{ Royal Jelly } \\
\hline & M & SD & M & SD & M & SD & M & SD & M & SD & M & SD & M & SD & M & SD & M & SD & M & SD \\
\hline $\mathrm{Al}$ & 0.09 & 0.02 & 0.187 & 0.078 & 6.33 & 0.43 & 2.48 & 0.22 & 0.153 & 0.027 & 0.439 & 0.035 & 1.65 & 0.03 & $<\mathrm{LOD}$ & - & 3.68 & 0.29 & 0.054 & 0.025 \\
\hline As & $<$ LOD & & $<$ LOD & & $<\mathrm{LOD}$ & & $<\mathrm{LOD}$ & & $<\mathrm{LOD}$ & & $<\mathrm{LOD}$ & & $<\mathrm{LOD}$ & & $<\mathrm{LOD}$ & - & 0.012 & 0.011 & $<$ LOD & \\
\hline B & 6.56 & 0.32 & 0.697 & 0.045 & 3.60 & 0.25 & 3.99 & 0.03 & 7.75 & 0.16 & 4.54 & 0.10 & 7.33 & 0.46 & $<\mathrm{LOD}$ & - & 5.73 & 0.67 & 1.37 & 0.16 \\
\hline Ва & 0.083 & 0.007 & $<$ LOD & & 1.93 & 0.08 & 0.627 & 0.043 & 0.0522 & 0.0053 & 0.113 & 0.011 & 0.891 & 0.061 & $<\mathrm{LOD}$ & - & 2.15 & 0.42 & $<$ LOD & \\
\hline $\mathrm{Be}$ & $<\mathrm{LOD}$ & 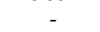 & $<\mathrm{LOD}$ & - & 0.00091 & 0.00016 & 0.00117 & 0.00019 & $<\mathrm{LOD}$ & . & $<\mathrm{LOD}$ & & 0.00183 & 0.00032 & $<\mathrm{LOD}$ & - & 0.00052 & 0.00037 & $<\mathrm{LOD}$ & - \\
\hline $\mathrm{Bi}$ & $<$ LOD & - & $<$ LOD & & 0.000516 & 0.000042 & $<\mathrm{LOD}$ & 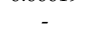 & $<$ LOD & - & 0.00057 & 0.00013 & 0.000270 & 0.000069 & $<\mathrm{LOD}$ & - & $<\mathrm{LOD}$ & & $<$ LOD & 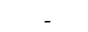 \\
\hline $\mathrm{Ca}$ & 91 & 6 & 38.6 & 8.7 & 181 & 24 & 154 & 21 & 51.1 & 6.8 & 50 & 12 & 118 & 8 & $<$ LOD & - & 547 & 103 & 165 & 43 \\
\hline $\mathrm{Cd}$ & 0.000218 & 0.000058 & $<$ LOD & & 0.00104 & 0.0003 & $<\mathrm{LOD}$ & & $<\mathrm{LOD}$ & & 00115 & 0.00022 & 0.00087 & 0.00010 & $<\mathrm{LOD}$ & 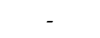 & 0.0 & 0.0063 & $<$ LOD & \\
\hline $\mathrm{Ce}$ & & 0.00015 & 0.000372 & 0.000087 & & & & 0.0 & & 0.00025 & & & & & 0.00 & 0.00023 & 0.0055 & 0.0026 & 0.000850 & 0.0002 \\
\hline Co & 0. & & 0. & 0.00031 & & & & & 0.0 & 0.00030 & & & & & & & & & & 0.00023 \\
\hline $\mathrm{Cr}$ & & & & & 0.0 & & 0.0 & & $<\mathrm{L}$ &.- & 0.01 & & 0.0 & 0.0 & 0.0 & 0.0060 & $\begin{array}{l}0.150 \\
0.0547\end{array}$ & 0.0061 & 0.0 & $\begin{array}{l}0.0026 \\
0.0020\end{array}$ \\
\hline Cs & & & & & & & 0.5 & 0. & 0.00 & 0.00065 & 0.00365 & 0.00013 & 0.547 & 0.037 & 0.000292 & 0.000091 & 0.0142 & 0.0034 & 0.00063 & 0.00013 \\
\hline $\mathrm{Cu}$ & 0.261 & 0.013 & 0.0623 & 0.0073 & 0.747 & 0.039 & 1.01 & 0.02 & 0.153 & 0.010 & 1.97 & 0.02 & 3.30 & 0.14 & $<\mathrm{LOD}$ & - & 5.82 & 0.89 & 4.26 & 0.41 \\
\hline $\mathrm{Fe}$ & 2.93 & 0.41 & 1.81 & 0.19 & 2.68 & 0.31 & 4.28 & 0.96 & 0.58 & 0.13 & 2.54 & 0.25 & 4.50 & 0.35 & 0.31 & 0.15 & 24.0 & 8.3 & 9.23 & 0.75 \\
\hline Ga & 0.00247 & 0.00035 & 0.00240 & 0.00029 & 0.042 & 0.011 & 0.0140 & 0.0012 & 0.00173 & 0.00035 & 0.00224 & 0.00048 & 0.0201 & 0.0025 & $<$ LOD & - & 0.0436 & 0.0072 & $<$ LOD & - \\
\hline $\mathrm{K}$ & 1340 & 24 & 89 & 2 & 4661 & 341 & 3708 & 36 & 732 & 8 & 6520 & 46 & 2399 & 157 & $<$ LOD & - & 3703 & 592 & 2520 & 260 \\
\hline
\end{tabular}




\section{Materials and Methods}

\subsection{Instrumentation}

A Bruker 820-MS quadrupole ICP-MS spectrometer (Bremen, Germany) equipped with a collision-reaction interface (CRI) and an Analytik Jena AG MicroMistTM glass nebulizer $\left(0.4 \mathrm{~mL} \mathrm{~min}^{-1}\right.$; Jena, Germany) was used for all the measurements. A radiofrequency power of $1.4 \mathrm{~kW}$, plasma gas flow rate of $18.0 \mathrm{~L} \mathrm{~min}^{-1}$, auxiliary gas flow rate of $1.8 \mathrm{~L} \mathrm{~min}^{-1}$ and nebulizer gas flow rate of $1.0 \mathrm{~L} \mathrm{~min}^{-1}$ were used. The monitored isotopes $(\mathrm{m} / \mathrm{z})$ are shown in Table 1 . The CRI with He and $\mathrm{H}_{2}(99.9995 \%$ purity; SOL Spa, Monza, Italy) as cell gases was used to quantify and remove polyatomic- and argon-based interference for As, $\mathrm{Cr}, \mathrm{Fe}, \mathrm{Mn}, \mathrm{Se}$, and V.

A Varian Vista MPX CCD Simultaneous ICP-OES spectrometer (Victoria, Mulgrave, Australia) in an axial configuration equipped with inert components (demountable torch with alumina injector, $1.8 \mathrm{~mm}$, and PTFE injector holder; Sturman-Masters inert spray chamber, double pass, white Ertalyte; Agilent, Santa Clara, CA, United States) was used to determine the residual C content (RCC) of the final digests and all the selected elements. A radiofrequency power of $1.0 \mathrm{~kW}$, plasma gas flow rate of 15.0 $\mathrm{L} \mathrm{min}^{-1}$, auxiliary gas flow rate of $1.5 \mathrm{~L} \mathrm{~min}^{-1}$, and nebulizer gas flow rate of $0.75 \mathrm{~L} \mathrm{~min}^{-1}$ were used as operational conditions. Elements were detected at the wavelength that maximized the signal intensity and minimized spectral overlaps (Table 1).

Ar gas (99.9995\% purity; SOL Spa, Monza, Italy) was used for plasma generation.

Analytical reagent-grade water with a resistivity of $18.2 \mathrm{M} \Omega \mathrm{cm}$ was obtained with an Arioso Power I RO-UP Scholar UV water purification system from Human Corporation (Songpa-Ku, Seoul, Korea).

An Argo Lab WB12 water bath (Modena, Italy) with an electronic temperature control was used for open-vessel digestion (method A), as described in Section 3.3.1. A maximum temperature and pressure up to $95^{\circ} \mathrm{C}\left( \pm 0.2^{\circ} \mathrm{C}\right)$ and $\sim 1$ bar, respectively, were used for this system.

A Milestone Ethos1 Touch Control microwave system (Sorisole, Bergamo, Italy) equipped with six PTFE or 20 quartz vessels was used for closed-vessel microwave digestion (methods B, B1 and B2), as described in Section 3.3.2. The vessels were irradiated with a maximum power of $1000 \mathrm{~W}$ and all the experiments were carried out at the maximum temperature $\left(180^{\circ} \mathrm{C}\right)$ and pressures of $\leq 40$ bar.

A Heto Power Dry LL1500 freeze dryer from Thermo Electron Corporation (Waltham, MA, USA) was employed for drying bee samples.

\subsection{Reagents}

Yttrium at $0.2 \mathrm{mg} \mathrm{L}^{-1}$ was used as the internal standard for ICP-OES and it was prepared from a standard stock solution (1000 $\pm 2 \mathrm{mg} \mathrm{L}^{-1}$; Panreac Química, Barcelona, Spain) [58]. Yttrium, Sc, Rh, In, and Th (1000 $\pm 5 \mathrm{mg} \mathrm{L}^{-1}$; Merck KGaA, Darmstadt, Germany) at $0.01 \mathrm{mg} \mathrm{L}^{-1}$ in a $1 \%(\mathrm{v} / \mathrm{v}) \mathrm{HNO}_{3}$ multistandard solution were employed as internal standards for ICP-MS [58,74].

$\mathrm{HNO}_{3}$ (67-70\%; super pure) from Carlo Erba Reagents S.r.l. (Milan, Italy), $\mathrm{HCl}$ (assay $>36 \%$; residue $<3 \mathrm{mg} \mathrm{L}^{-1}$ ), $\mathrm{HF}$ (assay $>40 \%$; residue $<2 \mathrm{mg} \mathrm{L}^{-1}$ ) and $\mathrm{H}_{2} \mathrm{O}_{2}$ (assay $>30 \%$ ) from Promochem, LGC Standards GmbH (Wesel, Germany) were used to prepare the standard and sample solution. All the reagents used were of analytical grade.

An apple leaf NIST 1515 was employed to evaluate the accuracy of the methods. The certified standard material was purchased from the National Institute of Standards and Technology (Gaithersburg, MD, USA).

ICP multielemental standard solutions of As, $\mathrm{Al}, \mathrm{Ba}, \mathrm{Be}, \mathrm{Bi}, \mathrm{Cd}, \mathrm{Cr}, \mathrm{Cs}, \mathrm{Cu}, \mathrm{Ga}, \mathrm{La}, \mathrm{Li}, \mathrm{Mn}, \mathrm{Mo}, \mathrm{Nb}$, $\mathrm{Ni}, \mathrm{Pb}, \mathrm{Rb}, \mathrm{Sb}, \mathrm{Se}, \mathrm{Sn}, \mathrm{Te}, \mathrm{Ti}, \mathrm{Tl}, \mathrm{U}, \mathrm{V}, \mathrm{W}$, and $\mathrm{Zr}$ at $1.000 \pm 0.005 \mathrm{mg} \mathrm{L}^{-1}, \mathrm{Ce}$ and Co at $5.00 \pm 0.03 \mathrm{mg}$ $\mathrm{L}^{-1}, \mathrm{Fe}$ and $\mathrm{Zn}$ at $10.00 \pm 0.05 \mathrm{mg} \mathrm{L}^{-1}, \mathrm{P}$ and $\mathrm{Si}$ at $50.00 \pm 0.25 \mathrm{mg} \mathrm{L}^{-1}, \mathrm{~B}$ and $\mathrm{Sr}$ at $55.00 \pm 0.25 \mathrm{mg} \mathrm{L}^{-1}$, $\mathrm{K}, \mathrm{Mg}$, and $\mathrm{Na}$ at $500.0 \pm 2.5 \mathrm{mg} \mathrm{L}^{-1}$, and $\mathrm{Ca}$ at $1000 \pm 5 \mathrm{mg} \mathrm{L}^{-1}$ in $3 \%(\mathrm{v} / \mathrm{v}) \mathrm{HNO}_{3}$, from Ultra Scientific/Agilent Technologies (North Kingstown, RI, USA), were used for the calibration procedure and spiked samples. 
A multielemental standard solution of $\mathrm{Ba}, \mathrm{Be}, \mathrm{Ce}, \mathrm{Co}, \mathrm{In}, \mathrm{Pb}, \mathrm{Mg}$, Tl, and Th $\left(10.00 \pm 0.05 \mathrm{mg} \mathrm{L}^{-1}\right.$ in $2 \% \mathrm{HNO}_{3}$ ) from Spectro Pure, Ricca Chemical Company (Arlington, TX, USA) was employed in order to select the best operating parameters for the ICP-MS analysis.

For the RCC assessment in the digested samples, a reference solution of $10,000 \mathrm{mg} \mathrm{L}^{-1}$ in C was prepared from anhydrous citric acid (assay $>99.5 \%$, ACS reagent; Sigma-Aldrich Chemie GmbH, Steinheim, Germany) in boiled deionized water, according to Muller et al., 2015 [49]. A standardized $\mathrm{NaOH}$ solution $\left(0.5 \mathrm{~mol} \mathrm{~L}^{-1}\right.$; assay $>98 \%$ sodium hydroxide anhydrous pellets, RPE for analysis, ACS and ISO; Carlo Erba Reagents, Milan, Italy) was prepared for the determination of residual acidity in final digested samples by acid-base titration.

\subsection{Sample Preparation Methods}

Ten samples of commercially available beehive products were collected from local supermarkets in Rome (Central Italy). The set of samples comprised several brands and consisted of five multifloral honeys, two honeydews, one pollen, one royal jelly and one beeswax cream.

The bee samples used for the recovery experiments were collected directly from the hive. At least 10 bees per sample with a wet weight of $\sim 2 \mathrm{~g}$ were brought to a stable dry weight after freeze-drying for $48 \mathrm{~h}$ and were finely grounded in a glass mortar. Specific portions of honeybees (30, 50, 100 and $200 \mathrm{mg}$ ) were analyzed to assess whether the weight of honeybees samples might be reduced. A mass of $200 \mathrm{mg}$ was selected for the subsequent analyses.

A volume of 1 or $2 \mathrm{~mL}$ of concentrated $\mathrm{HNO}_{3}$ for each digestion method was selected considering the maximum volume of the digestion vessels and the minimum dilution of the samples, in order to have a final acidity of $<5 \%$, as recommended by the ICP-MS manual. The bee samples with mass of $200 \mathrm{mg}$ and a reagent mixture ratio 1:2 of $\mathrm{H}_{2} \mathrm{O}_{2}$ and $\mathrm{HNO}_{3}$ were kept at maximum constant temperature of $95^{\circ} \mathrm{C}$ for the water bath and $180^{\circ} \mathrm{C}$ for the microwave oven, in accordance with previous studies [15,35,51]. Two commonly used digestion procedures with strong reagent mixtures [54-56], microwave aqua regia $+\mathrm{H}_{2} \mathrm{O}_{2}$ and microwave aqua regia $+\mathrm{HF}$, were used for the total digestion of elements in bees and beehive products samples. The sample analyses were carried out in duplicate. Certified reference material (NIST SRM 1515; three replicates) and blank digests (ten replicates) were subjected to the same sample preparation. All tested analytical procedures are described below.

\subsubsection{Open-Vessel Water Bath-Assisted Digestion}

A mass of $\sim 200 \mathrm{mg}$ for all samples was measured directly in an autosampler tube, $1 \mathrm{~mL}$ of $67 \%$ $\mathrm{HNO}_{3}$ and $0.5 \mathrm{~mL}$ of $30 \% \mathrm{H}_{2} \mathrm{O}_{2}$ were then added in the same tube. Subsequently, tubes were heated to $95 \pm 5^{\circ} \mathrm{C}$ in a water bath for $30 \mathrm{~min}$ (method A). After digestion, the mixture was left to cool and the contents of the tubes were diluted to 10 or $20 \mathrm{~mL}$ with deionized water for ICP-OES or ICP-MS analyses, respectively.

\subsubsection{Closed-Vessel Microwave-Assisted Digestion}

Weighed amounts ( $200 \mathrm{mg}$ ) of all samples were transferred into the microwave vessels. Then, $1 \mathrm{~mL} 67 \% \mathrm{HNO}_{3}, 0.5 \mathrm{~mL} 30 \% \mathrm{H}_{2} \mathrm{O}_{2}$, and $1.5 \mathrm{~mL}$ of deionized water (method $\mathrm{B}$ ) were added to the quartz vessels, and $1 \mathrm{~mL} 30 \% \mathrm{H}_{2} \mathrm{O}_{2}$ and $4 \mathrm{~mL}$ aqua regia (method $\mathrm{B} 1$ ) or $1 \mathrm{~mL} 40 \% \mathrm{HF}$ and $4 \mathrm{~mL}$ aqua regia (method B2) were added to the PTFE vessels. Subsequently, vessels were heated to $180^{\circ} \mathrm{C}$ with microwave energy (at a power of $1000 \mathrm{~W}$ ) for $40 \mathrm{~min}$. Cooled digests were transferred to the autosampler tubes. All digests by methods B and B1 were diluted to 10 or $20 \mathrm{~mL}$ with deionized water for the ICP-OES or ICP-MS analyses, respectively. The digests obtained with method B2 were diluted to a volume of $10 \mathrm{~mL}$ with deionized water for ICP-OES analysis.

\subsection{Quality Assurance and Control}

For the method validation, the selectivity, linearity, accuracy, LOD and LOQ were tested. According to the Eurachem Guide [75], accuracy, the closeness of agreement between a test result and 
the accepted reference value, is a parameter described by two contributions: the trueness bias or spike recovery and the precision. The accuracy was studied using a CRM and spiked samples for all the digestion methods or only for methods $\mathrm{A}$ and $\mathrm{B}$, respectively.

The comparison between the obtained results and the certified values of the CRM was carried out using Z-scores [71]. These were calculated according to the following formula:

$$
\left(\bar{X}_{\text {found }}-\bar{X}_{\text {certified }} /(S D / \sqrt{n})\right.
$$

where $\bar{X}_{\text {found }}$ is the result found by the analyst, $\bar{X}_{\text {certified }}$ is the certified value, SD is the standard deviation, and $\mathrm{n}$ is the number of independent replicates. Z-scores smaller than 2 are usually considered acceptable, Z-scores between 2 and 3 are questionable, and Z-scores larger than 3 are not satisfactory.

For recovery experiments, a spike solution was added to the samples at two levels before the sample digestion. Each digestion batch contained a reagent blank (matrix samples) to allow background correction.

The LODs were calculated with three times the relative standard deviation percentage (RSD\%) of ten method blanks multiplied by the background equivalent concentration (BEC)/100 [58], and the dilution factor used for sample preparation (Table S7). The LOQs were the lowest standard curve points that could be used for quantification (LLOQs). Together, the LLOQ and upper LOQ (ULOQ) define the linearity range.

At regular intervals (every 20 samples) during all analyses, an intermediate calibration standard was analyzed as a sample to monitor the instrument drift. A maximum percentage drift of $\pm 10 \%$ was considered acceptable for all the elements. Furthermore, calibration blanks $\left(3 \% \mathrm{HNO}_{3}\right)$ were frequently analyzed alongside samples to check any loss or cross contamination. Blanks were prepared by performing the full analytical procedure without samples.

The matrix effects on the sample uptake and nebulization were monitored by an internal standardization with Y for ICP-OES, and Y, Sc, Rh, In and Th for ICP-MS, and measurements were automatically corrected by the respective ICP software. Yttrium was not used as an internal standard for the ICP-MS analyses of the propolis samples because it is contained in the propolis in a concentration of $\sim 0.25 \mathrm{mg} \mathrm{kg}^{-1}\left(\sim 0.0025 \mathrm{mg} \mathrm{L}^{-1}\right.$ in digests). This concentration was negligible for ICP-OES analyses because $Y$ was added to the samples as an internal standard in a concentration of $0.2 \mathrm{mg} \mathrm{L}^{-1}$; therefore, in this case, $\mathrm{Y}$ was used as the internal standard for the propolis samples.

\subsection{Statistical Analysis}

All statistical calculations were made by the SPSS software package (IBMSPSS Statistics 25 software; IBM Corp., Armonk, NY, USA). Values < LOD were designated as LOD/2 [76]. The studies of significant differences were carried out by Mann-Whitney U or Kruskal-Wallis tests with pairwise post-hoc tests [77]. The difference in the results was considered statistically significant for $p$-values $<0.05$.

\section{Conclusions}

Unfortunately, the validation of methods and procedures used for the analysis of bees and beehive products is difficult because no CRMs of these matrices are available. Instead, the trueness of the methods and procedures applied is commonly checked by the analysis of different CRMs or by the recovery tests with samples spiked with known amounts of elements. It is worth noting that the study of elemental recovery in bees and beehive products may not allow for the evaluation of the efficiency of digestion procedures in decomposing the sample matrix. This in fact may not have the ability to readily absorb aqueous solutions containing known amounts of elements that should be released with only a complete digestion of the sample. In the present study, it is highlighted how each element in a specific matrix responds differently to the different sample treatment procedures used, thus allowing one to choose a specific method accordingly for the needs and purpose of the analysis. In screening analyses and biomonitoring studies, method A was a faster and a good alternative 
compared to microwave-assisted acid digestion for the determination of all the analyzed elements. Both the methods with mixture $\mathrm{HNO}_{3} / \mathrm{H}_{2} \mathrm{O}_{2}$ (methods $\mathrm{A}$ and $\mathrm{B}$ ) showed an acceptable accuracy for all the analyzed elements, and low levels of detection for trace elements including Pb. Considering all the tested methods, to have total levels of some elements (such as $\mathrm{Al}, \mathrm{B}, \mathrm{Ba}, \mathrm{Cr}, \mathrm{P}$, and $\mathrm{S}$ in bees; $\mathrm{Ba}, \mathrm{P}$, and $\mathrm{Ti}$ in beeswax; $\mathrm{Al}$, and $\mathrm{Ba}$ in honey; $\mathrm{Al}, \mathrm{B}, \mathrm{Ba}, \mathrm{Cr}, \mathrm{Cu}, \mathrm{Fe}, \mathrm{Na}, \mathrm{S}, \mathrm{Si}$, and Ti in pollen; $\mathrm{Al}, \mathrm{B}, \mathrm{Ba}, \mathrm{Be}$, $\mathrm{Ca}, \mathrm{Cd}, \mathrm{Co}, \mathrm{Cr}, \mathrm{Li}, \mathrm{Mg}, \mathrm{Si}, \mathrm{Sn}, \mathrm{Ti}, \mathrm{V}, \mathrm{Zn}$, and $\mathrm{Zr}$ in propolis; $\mathrm{Na}$, and $\mathrm{P}$ in royal jelly) is necessary to use an aqua regia mixture. This is very important for evaluating the quality of products and for preserving human health and the environment.

Supplementary Materials: The following are available online, Figure S1, Tables S1-S11.

Author Contributions: Conceptualization, M.L.A.; validation, M.L.A.; formal analysis, M.L.A.; investigation, M.L.A. and E.M.; resources, S.C. and M.E.C.; data curation, M.L.A.; writing-original draft preparation, M.L.A.; writing-review and editing, M.L.A., S.C., M.E.C. and L.M.; visualization, M.L.A. and E.M.; supervision, M.L.A. All authors have read and agreed to the published version of the manuscript.

Funding: This research received no external funding.

Acknowledgments: The authors wish to thank Massimo Marcolini and Marco Papi (Associazione Apicoltori Roma e Provincia) for their kind support in the bee sample collection.

Conflicts of Interest: The authors declare no conflict of interest.

\section{References}

1. Massimi, L.; Ristorini, M.; Astolfi, M.L.; Perrino, C.; Canepari, S. High resolution spatial mapping of element concentrations in PM10: A powerful tool for localization of emission sources. Atmos. Res. 2020, 244, 105060. [CrossRef]

2. Manigrasso, M.; Protano, C.; Astolfi, M.L.; Massimi, L.; Avino, P.; Vitali, M.; Canepari, S. Evidences of copper nanoparticle exposure in indoor environments: Long-term assessment, high-resolution field emission scanning electron microscopy evaluation, in silico respiratory dosimetry study and possible health implications. Sci. Total Environ. 2019, 653, 1192-1203. [CrossRef]

3. Canepari, S.; Castellano, P.; Astolfi, M.L.; Materazzi, S.; Ferrante, R.; Fiorini, D.; Curini, R. Release of particles, organic compounds, and metals from crumb rubber used in synthetic turf under chemical and physical stress. Environ. Sci. Pollut. Res. 2018, 25, 1448-1459. [CrossRef]

4. Canepari, S.; Astolfi, M.L.; Marcovecchio, F.; Maretto, M.; Perrino, C. Seasonal variations in the concentration and solubility of elements in atmospheric particulate matter: A case study in Northern Italy, E3S Web of Conferences. EDP Sci. 2013, 1, 20002. [CrossRef]

5. Marconi, E.; Canepari, S.; Astolfi, M.L.; Perrino, C. Determination of Sb (III), Sb (V) and identification of Sb-containing nanoparticles in airborne particulate matter. Procedia Environ. Sci. 2011, 4, 209-217. [CrossRef]

6. Astolfi, M.L.; Canepari, S.; Catrambone, M.; Perrino, C.; Pietrodangelo, A. Improved characterisation of inorganic components in airborne particulate matter. Environ. Chem. Lett. 2006, 3, 186-191. [CrossRef]

7. Al-Alam, J.; Chbani, A.; Faljoun, Z.; Millet, M. The use of vegetation, bees, and snails as important tools for the biomonitoring of atmospheric pollution-A review. Environ. Sci. Pollut. Res. 2019, 26, 9391-9408. [CrossRef]

8. Protano, C.; Canepari, S.; Astolfi, M.L.; de Meo, S.D.O.; Vitali, M. Urinary reference ranges and exposure profile for lithium among an Italian paediatric population. Sci. Total Environ. 2018, 619, 58-64. [CrossRef]

9. Astolfi, M.L.; Protano, C.; Marconi, E.; Massimi, L.; Piamonti, D.; Brunori, M.; Vitali, M.; Canepari, S. Biomonitoring of Mercury in Hair among a Group of Eritreans (Africa). Int. J.Environ. Res. Public Health 2020, 17, 1911. [CrossRef]

10. Astolfi, M.L.; Protano, C.; Schiavi, E.; Marconi, E.; Capobianco, D.; Massimi, L.; Ristorini, M.; Baldassarre, M.E.; Laforgia, N.; Vitali, M.; et al. A prophylactic multi-strain probiotic treatment to reduce the absorption of toxic elements: In-vitro study and biomonitoring of breast milk and infant stools. Environ. Int. 2019, 130, 104818. [CrossRef]

11. Ristorini, M.; Astolfi, M.L.; Frezzini, M.A.; Canepari, S.; Massimi, L. Evaluation of the efficiency of Arundo donax L. leaves as biomonitors for atmospheric element concentrations in an urban and industrial area of central Italy. Atmosphere 2020, 11, 226. [CrossRef] 
12. Vitali, M.; Antonucci, A.; Owczarek, M.; Guidotti, M.; Astolfi, M.L.; Manigrasso, M.; Avino, P.; Bhattacharya, B.; Protano, C. Air quality assessment in different environmental scenarios by the determination of typical heavy metals and Persistent Organic Pollutants in native lichen Xanthoria parietina. Environ. Pollut. 2019, 254, 113013. [CrossRef]

13. Massimi, L.; Conti, M.E.; Mele, G.; Ristorini, M.; Astolfi, M.L.; Canepari, S. Lichen transplants as indicators of atmospheric element concentrations: A high spatial resolution comparison with PM10 samples in a polluted area (Central Italy). Ecol. Indic. 2019, 101, 759-769. [CrossRef]

14. Conti, M.E.; Canepari, S.; Finoia, M.G.; Mele, G.; Astolfi, M.L. Characterization of Italian multifloral honeys on the basis of their mineral content and some typical quality parameters. J. Food Compos. Anal. 2018, 74, 102-113. [CrossRef]

15. Losfeld, G.; Saunier, J.B.; Grison, C. Minor and trace-elements in apiary products from a historical mining district (Les Malines, France). Food Chem. 2014, 146, 455-459. [CrossRef]

16. Dżugan, M.; Wesołowska, M.; Zaguła, G.; Kaczmarski, M.; Czernicka, M.; Puchalski, C. Honeybees (Apis mellifera) as a biological barrier for contamination of honey by environmental toxic metals. Environ. Monit. Assess. 2018, 190, 101. [CrossRef]

17. Lambert, O.; Piroux, M.; Puyo, S.; Thorin, C.; Larhantec, M.; Delbac, F.; Pouliquen, H. Bees, honey and pollen as sentinels for lead environmental contamination. Environ. Pollut. 2012, 170, 254-259. [CrossRef]

18. Zhou, X.; Taylor, M.P.; Davies, P.J.; Prasad, S. Identifying sources of environmental contamination in European honey bees (Apis mellifera) using trace elements and lead isotopic compositions. Environ. Sci. Technol. 2018, 52, 991-1001. [CrossRef]

19. Matin, G.; Kargar, N.; Buyukisik, H.B. Bio-monitoring of cadmium, lead, arsenic and mercury in industrial districts of Izmir, Turkey by using honey bees, propolis and pine tree leaves. Ecol. Eng. 2016, 90, 331-335. [CrossRef]

20. Smith, K.E.; Weis, D.; Amini, M.; Shiel, A.E.; Lai, V.W.M.; Gordon, K. Honey as a biomonitor for a changing world. Nat. Sustain. 2019, 2, 223-232. [CrossRef]

21. Pohl, P.; Sergiel, I.; Stecka, H. Determination and fractionation of metals in honey. Crit. Rev. Anal. Chem. 2009, 39, 276-288. [CrossRef]

22. Herrero-Latorre, C.; Barciela-García, J.; García-Martín, S.; Peña-Crecente, R.M. The use of honeybees and honey as environmental bioindicators for metals and radionuclides: A review. Environ. Rev. 2017, 25, 463-480. [CrossRef]

23. Pascual-Maté, A.; Osés, S.M.; Fernández-Muiño, M.A.; Sancho, M.T. Methods of analysis of honey. J. Apic. Res. 2018, 57, 38-74. [CrossRef]

24. Álvarez-Ayuso, E.; Abad-Valle, P. Trace element levels in an area impacted by old mining operations and their relationship with beehive products. Sci. Total Environ. 2017, 599, 671-678. [CrossRef] [PubMed]

25. van der Steen, J.J.; de Kraker, J.; Grotenhuis, T. Spatial and temporal variation of metal concentrations in adult honeybees (Apis mellifera L.), Environ. Monit. Assess. 2012, 184, 4119-4126. [CrossRef]

26. Ajtony, Z.; Bencs, L.; Haraszi, R.; Szigeti, J.; Szoboszlai, N. Study on the simultaneous determination of some essential and toxic trace elements in honey by multi-element graphite furnace atomic absorption spectrometry. Talanta 2007, 71, 683-690. [CrossRef]

27. Packer, A.P.; Giné, M.F. Analysis of undigested honey samples by isotope dilution inductively coupled plasma mass spectrometry with direct injection nebulization (ID-ICP-MS). Spectrochim. Acta B 2001, 56, 69-75. [CrossRef]

28. Madejczyk, M.; Baralkiewicz, D. Characterization of Polish rape and honeydew honey according to their mineral contents using ICP-MS and F-AAS/AES. Anal. Chim. Acta 2008, 617, 11-17. [CrossRef]

29. Conti, M.E.; Botrè, F. Honeybees and their products as potential bioindicators of heavy metals contamination. Environ. Monit. Assess. 2001, 69, 267-282. [CrossRef]

30. Gutiérrez, M.; Molero, R.; Gaju, M.; van der Steen, J.; Porrini, C.; Ruiz, J.A. Assessment of heavy metal pollution in Córdoba (Spain) by biomonitoring foraging honeybee. Environ. Monit. Assess. 2015, 18, 651. [CrossRef]

31. Sajtos, Z.; Herman, P.; Harangi, S.; Baranyai, E. Elemental analysis of Hungarian honey samples and bee products by MP-AES method. Microchem. J. 2019, 149, 103968. [CrossRef]

32. Mračević, S.Đ.; Krstić, M.; Lolić, A.; Ražić, S. Comparative study of the chemical composition and biological potential of honey from different regions of Serbia. Microchem. J. 2020, 152, 104420. [CrossRef] 
33. Bazeyad, A.Y.; Al-Sarar, A.S.; Rushdi, A.I.; Hassanin, A.S.; Abobakr, Y. Levels of heavy metals in a multifloral Saudi honey. Environ. Sci. Pollut. Res. 2019, 26, 3946-3953. [CrossRef]

34. Oliveira, S.S.; Alves, C.N.; Morte, E.S.B.; Júnior, A.D.F.S.; Araujo, R.G.O.; Santos, D.C.M.B. Determination of essential and potentially toxic elements and their estimation of bioaccessibility in honeys. Microchem. J. 2019, 151, 104221. [CrossRef]

35. Grainger, M.N.; Hewitt, N.; French, A.D. Optimised approach for small mass sample preparation and elemental analysis of bees and bee products by inductively coupled plasma mass spectrometry. Talanta 2020, 214, 120858. [CrossRef]

36. Sadowska, M.; Gogolewska, H.; Pawelec, N.; Sentkowska, A.; Krasnodębska-Ostrega, B. Comparison of the contents of selected elements and pesticides in honey bees with regard to their habitat. Environ. Sci. Pollut. Res. 2019, 26, 371-380. [CrossRef]

37. Giglio, A.; Ammendola, A.; Battistella, S.; Naccarato, A.; Pallavicini, A.; Simeon, E.; Tagarelli, A.; Giulianini, P.G. Apis mellifera ligustica, Spinola 1806 as bioindicator for detecting environmental contamination: A preliminary study of heavy metal pollution in Trieste, Italy. Environ. Sci. Pollut. Res. 2017, 24, 659-665. [CrossRef]

38. González-Martín, M.I.; Revilla, I.; Betances-Salcedo, E.V.; Vivar-Quintana, A.M. Pesticide residues and heavy metals in commercially processed propolis. Microchem. J. 2018, 143, 423-429. [CrossRef]

39. Voica, C.; Iordache, A.M.; Ionete, R.E. Multielemental characterization of honey using inductively coupled plasma mass spectrometry fused with chemometrics. J. Mass Spectrom. 2020, 55, e4512. [CrossRef]

40. Raeymaekers, B. A prospective biomonitoring campaign with honey bees in a district of Upper-Bavaria (Germany). Environ. Monit. Assess. 2006, 116, 233-243. [CrossRef]

41. Vieira, H.P.; Nascentes, C.C.; Windmöller, C.C. Development and comparison of two analytical methods to quantify the mercury content in honey. J. Food Compos. Anal. 2014, 34, 1-6. [CrossRef]

42. Morgano, M.A.; Martins, M.C.T.; Rabonato, L.C.; Milani, R.F.; Yotsuyanagi, K.; Rodriguez-Amaya, D.B. A comprehensive investigation of the mineral composition of Brazilian bee pollen: Geographic and seasonal variations and contribution to human diet. J. Braz. Chem. Soc. 2012, 23, 727-736. [CrossRef]

43. da Silva, P.M.; Gauche, C.; Gonzaga, L.V.; Costa, A.C.O.; Fett, R. Honey: Chemical composition, stability and authenticity. Food Chem. 2016, 196, 309-323. [CrossRef] [PubMed]

44. Bastos, D.H.M.; Bastos, M.; Barth, O.M.; Rocha, C.I.; Cunha, I.B.d.S.; de Carvalho, P.; Torres, E.A.S.; Michelan, M. Fatty acid composition and palynological analysis of bee (Apis) pollen loads in the states of São Paulo and Minas Gerais. Brazil. J. Apic. Res. 2004, 43, 35-39. [CrossRef]

45. Pettine, M.; Casentini, B.; Mastroianni, D.; Capri, S. Dissolved inorganic carbon effect in the determination of arsenic and chromium in mineral waters by inductively coupled plasma-mass spectrometry. Anal. Chim. Acta 2007, 599, 191-198. [CrossRef]

46. Allain, P.; Jaunault, L.; Mauras, Y.; Mermet, J.M.; Delaporte, T. Signal enhancement of elements due to the presence of carbon-containing compounds in inductively coupled plasma mass spectrometry. Anal. Chem. 1991, 63, 1497-1498. [CrossRef]

47. US EPA. SW-846 Test Method 6020B: Inductively Coupled Plasma-Mass Spectrometry; United States Environmental Protection Agency: Cincinnati, OH, USA, 1994.

48. Nóbrega, J.A.; Pirola, C.; Fialho, L.L.; Rota, G.; de Campos Jordão, C.E.K.M.A.; Pollo, F. Microwave-assisted digestion of organic samples: How simple can it become? Talanta 2012, 98, 272-276. [CrossRef]

49. Muller, A.L.; Oliveira, J.S.; Mello, P.A.; Muller, E.I.; Flores, E.M. Study and determination of elemental impurities by ICP-MS in active pharmaceutical ingredients using single reaction chamber digestion in compliance with USP requirements. Talanta 2015, 136, 161-169. [CrossRef]

50. Latimer, G.W.; Association of Official Analytical Chemists International (AOAC). Official Methods of Analysis of AOAC International; AOAC International: Gaithersburg, MD, USA, 2012.

51. Bilandžić, N.; Đokić, M.; Sedak, M.; Kolanović, S.B.; Varenina, I.; Končurat, A.; Rudan, N. Determination of trace elements in Croatian floral honey originating from different regions. Food Chem. 2011, 128, 1160-1164. [CrossRef]

52. Leme, A.B.; Bianchi, S.R.; Carneiro, R.L.; Nogueira, A.R. Optimization of sample preparation in the determination of minerals and trace elements in honey by ICP-MS. Food Anal. Methods 2014, 7, 1009-1015. [CrossRef] 
53. Döker, S.; Aydemir, O.; Uslu, M. Evaluation of digestion procedures for trace element analysis of Cankiri, Turkey honey by inductively coupled plasma mass spectrometry. Anal. Lett. 2014, 47, 2080-2094. [CrossRef]

54. Chen, M.; Ma, L.Q. Comparison of three aqua regia digestion methods for twenty Florida soils. Soil Sci. Soc. Am. J. 2001, 65, 491-499. [CrossRef]

55. Abbruzzini, T.F.; Silva, C.A.; Andrade, D.A.D.; Carneiro, W.J.D.O. Influence of digestion methods on the recovery of iron, zinc, nickel, chromium, cadmium and lead contents in 11 organic residues. Rev. Bras. Ciênc. Sol. 2014, 38, 166-176. [CrossRef]

56. Das, S.; Ting, Y.P. Evaluation of wet digestion methods for quantification of metal content in electronic scrap material. Resources 2017, 6, 64. [CrossRef]

57. Edgell, K. USEPA Method Study 37 SW-846 Method 3050 Acid Digestion of Sediments, Sludges, and Soils; US Environmental Protection Agency, Environmental Monitoring Systems Laboratory: Washington, DC, USA, 1989.

58. Astolfi, M.L.; Protano, C.; Marconi, E.; Massimi, L.; Brunori, M.; Piamonti, D.; Migliara, G.; Vitali, M.; Canepari, S. A new treatment of human hair for elemental determination by inductively coupled mass spectrometry. Anal. Methods 2020, 12, 1906-1918. [CrossRef]

59. Bizzi, C.A.; Barin, J.S.; Garcia, E.E.; Nóbrega, J.A.; Dressler, V.L.; Flores, E.M. Improvement of microwaveassisted digestion of milk powder with diluted nitric acid using oxygen as auxiliary reagent. Spectrochim. Acta $B$ 2011, 66, 394-398. [CrossRef]

60. Astolfi, M.L.; Marconi, E.; Protano, C.; Vitali, M.; Schiavi, E.; Mastromarino, P.; Canepari, S. Optimization and validation of a fast digestion method for the determination of major and trace elements in breast milk by ICP-MS. Anal. Chim. Acta 2018, 1040, 49-62. [CrossRef]

61. Phan-Thien, K.Y.; Wright, G.C.; Lee, N.A. Inductively coupled plasma-mass spectrometry (ICP-MS) and-optical emission spectroscopy (ICP-OES) for determination of essential minerals in closed acid digestates of peanuts (Arachis hypogaea L.). Food Chem. 2012, 134, 453-460. [CrossRef]

62. Pick, D.; Leiterer, M.; Einax, J.W. Reduction of polyatomic interferences in biological material using dynamic reaction cell ICP-MS. Microchem. J. 2010, 95, 315-319. [CrossRef]

63. D’Ilio, S.; Petrucci, F.; D’Amato, M.; di Gregorio, M.; Senofonte, O.; Violante, N. Method validation for determination of arsenic, cadmium, chromium and lead in milk by means of dynamic reaction cell inductively coupled plasma mass spectrometry. Anal. Chim. Acta 2008, 624, 59-67. [CrossRef]

64. May, T.W.; Wiedmeyer, R.H. A table of polyatomic interferences in ICP-MS. At. Spectrosc. 1998, 19, $150-155$.

65. Martínez-Sierra, J.G.; San Blas, O.G.; Gayón, J.M.; Alonso, J.G. Sulfur analysis by inductively coupled plasma-mass spectrometry: A review. Spectrochim. Acta B 2015, 108, 35-52. [CrossRef]

66. Mandel, J. The Statistical Analysis of Experimental Data; John Wiley \& Sons: New York, NY, USA, 1964; pp. $1-410$.

67. Cubadda, F.; Raggi, A.; Testoni, A.; Zanasi, F. Multielemental analysis of food and agricultural matrixes by inductively coupled plasma-mass spectrometry. J. AOAC Int. 2002, 85, 113-121. [CrossRef]

68. Nardi, E.P.; Evangelista, F.S.; Tormen, L.; Pierre, T.D.S.; Curtius, A.J.; de Souza, S.S.; Junior, F.B. The use of inductively coupled plasma mass spectrometry (ICP-MS) for the determination of toxic and essential elements in different types of food samples. Food Chem. 2009, 112, 727-732. [CrossRef]

69. European Commission. Commission Regulation (EU) 2015/1005 of 25 June 2015 amending Regulation (EC) No 1881/2006 as regards maximum levels of lead in certain foodstuffs. Off. J. Eur. Union 2015, 161, 9-13.

70. Codex Alimentarius. Joint FAO/WHO Food Standards Programme; Twenty-fourth Session; Codex Alimentarius Commission: Geneva, Switzerland, 2001.

71. Jorhem, L.; Engman, J.; Schröder, T. Evaluation of results derived from the analysis of certified reference materials-a user-friendly approach based on simplicity. Fresenius J. Anal. Chem. 2001, 370, 178-182. [CrossRef]

72. U.S. EPA. Method 3051A (SW-846): Microwave Assisted Acid Digestion of Sediments, Sludges, and Oils; Revision 1; United States Environmental Protection Agency: Washington, DC, USA, 2007.

73. Cava-Montesinos, P.; Cervera, M.L.; Pastor, A.; de la Guardia, M. Room temperature acid sonication ICP-MS multielemental analysis of milk. Anal. Chim. Acta 2005, 531, 111-123. [CrossRef]

74. Astolfi, M.L.; Marconi, E.; Protano, C.; Canepari, S. Comparative elemental analysis of dairy milk and plant-based milk alternatives. Food Control 2020, 116, 107327. [CrossRef] 
75. Magnusson, B.; Örnemark, U. (Eds.) Eurachem Guide: The Fitness for Purpose of Analytical Methods-A Laboratory Guide to Method Validation and Related Topics, 2nd ed.; Eurachem: Teddington, UK, 2014; ISBN 978-91-87461-59-0. Available online: www.eurachem.org (accessed on 7 September 2020).

76. Hornung, R.W.; Reed, L.D. Estimation of average concentration in the presence of nondetectable values. Appl. Occup. Environ. Hyg. 1990, 5, 46-51. [CrossRef]

77. Siegel, S.; Castellan, N.J., Jr. Non Parametric Statistics for the Behavioral Sciences, 2nd ed.; McGraw-Hill: Milan, Italy, 1992; p. 477.

Sample Availability: Not available.

(C) 2020 by the authors. Licensee MDPI, Basel, Switzerland. This article is an open access article distributed under the terms and conditions of the Creative Commons Attribution (CC BY) license (http://creativecommons.org/licenses/by/4.0/). 